\title{
Tien jaar Belgische Collectieve Schuldenregeling (kritisch) geëvalueerd
}

\author{
Bertel De Groote en Stefaan Voet*
}

\section{Inleiding}

\section{I.I Wettelijk kader}

I. De Belgische collectieve schuldenregeling is tien jaar oud. De regeling werd door de op I januari 1999 in werking getreden wet van 5 juli 1998 betreffende de collectieve schuldenregeling en de mogelijkheid van de verkoop uit de hand van de in beslag genomen onroerende goederen in het Gerechtelijk Wetboek verankerd. ${ }^{\mathrm{I}} \mathrm{De}$ procedure, een na langdurig overleg tot stand gekomen evenwicht, maakte deel uit van de meer algemene strijd tegen de armoede.

De wetgever had met de collectieve schuldenregeling een tweeledig doel voor ogen. Enerzijds het aanreiken van een 'fresh start' - in de vorm van een menswaardig leven - aan zij die het hoofd niet meer kunnen bieden aan een overmatige schuldenlast. Anderzijds ervoor te zorgen dat deze schuldenaren - in de mate van het mogelijke - hun schulden alsnog kunnen aanzuiveren. ${ }^{2}$

De procedure bleek echter gepaard te gaan met een aantal technische onvolmaaktheden die in de loop der jaren aan de oppervlakte kwamen. Zij betroffen zowel de beschikking van toelaatbaarheid en haar gevolgen, de minnelijke en gerechtelijke aanzuiveringsregeling en haar opvolging, als het einde van de collectieve schulden-

* Bertel De Groote is docent aan de Hogeschool Gent, Departement Handelswetenschappen en Bestuurskunde. Stefaan Voet is assistent voor het Instituut Procesrecht Universiteit Gent en advocaat van de balie Brugge.

1. B.S. 3 I juli I998, err. B.S. I8 september I998. Voor een aantal commentaren bij de initiële procedure zie E. Dirix en P. Taelman (eds.), Collectieve schuldenregeling in de praktijk, Antwerpen, Intersentia, I999, 306 p.; B. De Groote, De collectieve schuldenregeling, Antwerpen, Kluwer, I999, 2I6 p. en G. De Leval, La loi du 5 juillet 1998 relative au règlement collectief de dettes et à la possibilité de vente de gré à gré des biens immeubles saisis, Liège, Collection Scientifique de la Faculté de droit de Liège, 1998, I73 p.

2. Wetsontwerpen betreffende de collectieve schuldenregeling en de mogelijkheid van de verkoop uit de hand van de in beslag genomen onroerende goederen en tot wijziging van de artikelen 628 en I395 van het Gerechtelijk Wetboek, Parl. St. Kamer 1996-97, nrs. I073/I - I074/I, I9. 
regeling. Met wisselend succes hebben rechtspraak en rechtsleer oplossingen uitgewerkt voor deze knelpunten. ${ }^{3}$

2. In 2005 heeft de Belgische wetgever de collectieve schuldenregeling bijgespijkerd. De herziening, waarvan de inwerkingtreding in 2007 zijn volle uitwerking heeft gekregen, moest de procedure optimaliseren, onder meer door een einde te maken aan een aantal belangrijke knelpunten die de toepassing van de procedure hadden gekenmerkt.

De wijziging werd gerealiseerd door twee wetten van 13 december $2005: 4$ de wet van I3 december 2005 tot wijziging van de artikelen 8I, I04, 569, 578, 580, 583 en I395 van het Gerechtelijk Wetboek ${ }^{5}$ en de wet van I3 december 2005 houdende bepalingen betreffende de termijnen, het verzoekschrift op tegenspraak en de procedure van collectieve schuldenregeling. ${ }^{6}$

Eerstgenoemde wet hevelde de bevoegdheid met betrekking tot de collectieve schuldenregeling over van de beslagrechter in de rechtbank van eerste aanleg naar de arbeidsgerechten. Deze overdracht kadert volgens de wetgever in een versterkte aandacht voor het sociale aspect van de problematiek waaraan de collectieve schuldenregeling wil verhelpen.

3. Zie bijvoorbeeld - niet exhaustief - K. Broeckx en B. De Groote, 'Collectieve schuldenregeling in de praktijk', in E. Dirix en P. Taelman (eds.), Beslag- en Executierecht. Naar een collectief beslagrecht, Antwerpen-Groningen, Intersentia Rechtswetenschappen, 2001, 157-234; P. Dauw, B. Wylleman en W. De Gendt, 'De collectieve schuldenregeling. Vragen \& Antwoorden', in X., Hogeschool WestVlaanderen. Departement Simon Stevin, Posthogeschoolvorming Rechtspraktijk, Gent, Academia Press, 2003, 83-I87; B. De Groote, 'Tien knelpunten inzake collectieve schuldenregeling', in X., Beslag en Collectieve Schuldenregeling (Vormingsprogramma 2003-2004. Orde van Advocaten Kortrijk), Gent, Larcier, 2005, 2I-98; E. Dirix, 'Beslag en collectieve schuldenregeling. Overzicht van rechtspraak (I997-200I)', T.P.R. 2002, I29I-I324, nrs. I48-I98 en K. Loontjens, 'Enkele praktische problemen in verband met de collectieve schuldenregeling', in X., Beslag en Collectieve Schuldenregeling (Vormingsprogramma 2003-2004. Orde van Advocaten Kortrijk), Gent, Larcier, 2005, 99-I20. De rechtspracticus moet ongetwijfeld verwezen worden naar E. Van Acker en B. Wylleman, Praktische gids voor schuldbemiddelaars, Mechelen, Kluwer, 2006, $470 \mathrm{p}$.

4. Over deze twee wetten zie - niet exhaustief - K. Broeckx, B. De Groote en S. Voet, 'Grondige revisie van de collectieve schuldenregeling', T.P.R. 2007, I547-I649; B. De Groote, 'Collectieve schuldenregeling. Fundamentele wijzigingen 2005', NjW 2006, 242-250; B. De Groote, 'Collectieve schuldenregeling anno 2006', Ad Rem 2006, nr. 3, Io-22; B. De Groote en S. Voet, 'De vernieuwde Wet op de Collectieve Schuldenregeling', P.\&B. 2007, I3I-I63; B. De Groote en S. Voet, 'Verkenning van de vernieuwde collectieve schuldenregeling', D.C.C.R. 2006, 5-62; G. De Leval, V. Grella, J.-L. Ledoux, 'Règlement collectif de dettes', in G. De Leval (ed.), Actualités en droit judiciaire (Commission Université-Palais), Brussel, Larcier, 2005, 265-282 (in het bijzonder Section 2- Synthèse du droit nouveau); V. Grella, 'Le règlement collectif de dettes. Première réforme et nouveautés', J.T. 2006, 685-695; J.-L. Ledoux, 'Règlement collectif de dettes. Droit nouveau - Concours et sûretés', Rev. not. b. 2006, 6-28; J.-L. Ledoux, 'Règlement collectif de dettes. Droit nouveau - Concours et sûretés. Corrigendum et addendum', Rev. not. b. 2006, I35-136; P. Taelman en S. Voet, 'Enkele inhoudelijke innovaties inzake collectieve schuldenregeling', in X., Rechtskroniek voor het Notariaat - deel 9, Brugge, die Keure, 2006, I-I7; B. Vanermen, 'De belastingontvangers kunnen weldra kwijtschelding van fiscale schulden aanvaarden', R.W. 2005-06, I292-I299; A. Vareman, 'De collectieve schuldenregeling naar de arbeidsrechtbank', R.W. 2005-06, I28I-I292 en S. Voet, 'Nieuwigheden inzake collectieve schuldenregeling: een eerste verkenning', Waarvan Akte 2006, 60-73.

5. B.S. 2 I december 2005 , eerste uitg.

6. B.S. 2I december 2005, eerste uitg. 
De tweede wet wijzigde de procedure op een aantal punten. De wijziging is grondig, maar laat de essentie van de structuur grotendeels ongemoeid. Binnen het bestaande raamwerk van de procedure zijn de inhoudelijke wijzigingen betekenisvol en vaak grensverleggend. De wetgever heeft, bijvoorbeeld met betrekking tot het lot van de borgen van de schuldenaar in de collectieve schuldenregeling of op het gebied van de prioritaire betaling van bepaalde schulden van de schuldenaar, duidelijke beleidskeuzes gemaakt. De behandeling van de borgen, die geïnspireerd is door de faillissementswetgeving, illustreert ook de zorg van de wetgever om de burgerlijke en commerciële insolventieprocedures nauwer bij elkaar te laten aansluiten.

3. Dit preadvies heeft een ander doel dan een juridisch-technische analyse van de (gewijzigde) collectieve schuldenregeling. Zij zal de lezer weliswaar vertrouwd proberen te maken met de gewijzigde procedure, doch wil hem daarbij vooral toelaten de hervormde procedure te evalueren. Dit vergt een andere invalshoek.

\section{I.2 Verantwoording}

4. Als een rechtsorde wordt beschouwd als een aggregaat van achterliggende individuele realiteiten en verhoudingen in de samenleving, moet worden vastgesteld dat het op macroniveau tot stand gekomen juridisch kader niet noodzakelijk in het verlengde ligt van de maatschappelijke context op microniveau. De collectieve schuldenregeling is een uitgelezen illustratie van dit spanningsveld. Tegelijk probeert deze procedure dit spanningsveld te beheersen, met als achterliggend doel de financiële re-integratie van de betrokken schuldenaar in de samenleving. De collectieve schuldenregeling balanceert bijgevolg tussen de individuele belangen van de rechtstreeks betrokken partijen i.c. de schuldenaar en zijn schuldeisers - en de maatschappelijke belangen. De confrontatie van deze, zich respectievelijk op het micro- en het macroniveau situerende, belangen wordt bij de problematiek van de overmatige schuldenlast duidelijk.

Een drietal voorbeelden kunnen dit verduidelijken.

De collectieve schuldenregeling bevindt zich op de breuklijn tussen het in art. II 34 B.W. tot uitdrukking gebrachte adagium pacta sunt servanda enerzijds en de concrete en structurele onmogelijkheid voor een particulier om zijn schulden te betalen anderzijds. Om aan deze structurele onmogelijkheid, die de financiële participatie van de schuldenaar in het gedrang brengt, te verhelpen heeft de collectieve schuldenregeling tot doel door middel van een aanzuiveringsregeling de financiële toestand van de schuldenaar te herstellen. Zij stelt hem in staat in de mate van het mogelijke zijn schulden af te betalen. Aangezien de terugbetalingscapaciteit wordt bepaald door het belang dat de maatschappij hecht aan het waarborgen van een menswaardig leven voor de schuldenaar en zijn gezin, kan laatstgenoemd grondwettelijk beschermd recht tot gevolg hebben dat financieel herstel noodzakelijkerwijze een schuldkwijtschelding impliceert en in sommige gevallen zelfs het opleggen van een aanzuiveringsregeling uitsluit. ${ }^{7}$ Een ander voorbeeld vormt de wijze waarop de

7. Zie het hierna te bespreken art. $1675 / \mathrm{I} 3$ bis Ger. W. met betrekking tot de totale kwijtschelding van schulden zonder aanzuiveringsregeling. 
procedure de grondregel van de gelijkheid onder de schuldeisers enerzijds beklemtoont en anderzijds in bepaalde hypotheses doorkruist omwille van de zorg voor de menswaardige leefomstandigheden van de schuldenaar en zijn gezin. Een laatste voorbeeld betreft de wijze waarop de procedure van collectieve schuldenregeling, naar analogie van het faillissementsrecht, met betrekking tot de figuur van de persoonlijke zekerheidsstelling een evenwicht zoekt tussen de belangen van de zekerheidssteller en de schuldeiser van de verbintenis waarop de zekerheidsstelling betrekking heeft. Om - in een sneeuwbaleffect - overmatige schuldenlast in hoofde van de kosteloze zekerheidssteller (natuurlijke persoon) te vermijden, tast de wetgever het wezenskenmerk van de borgstelling aan door de mogelijkheid tot bevrijding in hoofde van de zekerheidssteller te introduceren bij onevenredigheid van hun verbintenis met hun inkomsten en vermogen. ${ }^{8}$

5. De collectieve schuldenregeling vertaalt conflicterende individuele en maatschappelijke belangen in een complexe evenwichtsoefening tussen onderscheiden rechtsregels en juridische concepten. Dit evenwicht vindt tevens zijn weerslag in de positie van en tussen de verschillende bij de collectieve schuldenregeling betrokken actoren, waarop voormelde belangen betrekking hebben. Vandaar dat ook de sociale relevantie van de procedure moet worden benadrukt. In het bijzonder moet aandacht worden besteed aan de vraag of en hoe sociale overwegingen de keuzes van de wetgever bij de vormgeving van de aanzuiveringsprocedure en de erin vervatte belangenafweging hebben beïnvloed. Vanuit dit oogpunt zal worden geïllustreerd hoe de sociale zorg, zoals het re-integrerende oogmerk, de collectieve schuldenregeling van andere insolventieprocedures, respectievelijk het gerechtelijk akkoord en het faillissement, onderscheidt. Terwijl bij het faillissement de opruiming van dood economisch weefsel en de optimale verdeling van de boedel tussen de schuldeisers centraal staat, heeft de collectieve schuldenregeling tot doel financieel fragiel weefsel te herstellen. Anders dan bij het gerechtelijk akkoord, gebeurt dit met evenwichtige aandacht voor de situatie van de schuldenaar en zijn gezin.

6. De collectieve schuldenregeling verdient eveneens aandacht omdat zij de wijze illustreert waarop de wetgever de beperkingen van de impact van zijn optreden aftast. Door middel van een aanzuiveringsregeling wordt getracht de financiële reintegratie van een niet-handelaar met overmatige schuldenlast te bewerkstelligen. De vraag rijst echter in hoeverre de procedure niet enkel de symptomen bestrijdt, maar de re-integratie tevens een structureel karakter geeft. Het is immers vaak een kluwen van diverse achterliggende redenen die niet noodzakelijk rechtstreeks van financiële aard zijn die leiden tot de duurzame onmogelijkheid voor de schuldenaar om zijn opeisbare en nog te vervallen schulden te betalen (bijvoorbeeld gezondheidsproblemen, verslaving, werkloosheid, relationele moeilijkheden enz.). Het ligt voor de wetgever bijgevolg niet voor de hand in het juridisch kader waarin op de situatie van overmatige schuldenlast wordt geanticipeerd de onderliggende problemen te integreren. Niettemin is hij hierom bekommerd, zoals blijkt uit de aan de rechter

8. Zie art. I675/16bis Ger. W. 
verleende bevoegdheid om de aanzuiveringsmaatregelen afhankelijk te maken van de vervulling van passende handelingen door de schuldenaar om de betaling van de schuld te waarborgen of te vergemakkelijken.

7. Ondanks deze veelheid aan juridische uitdagingen waartussen de collectieve schuldenregeling laveert, heeft dit preadvies niet tot doel de procedure en de ermee gepaard gaande interpretatie- en toepassingsmoeilijkheden juridisch-technisch uit te vlooien. In de schaduw van de tiende verjaardag van de wet van 5 juli 1998, wil dit advies een evaluatie van de Belgische insolventieprocedure voor particulieren voorstellen. Dit voorstel moet tevens de beleidsvisie die de wetgever bij de uitbouw van de procedure tot uitdrukking heeft willen brengen, verduidelijken. Daarenboven moet de evaluatie voor de lezer de kernelementen waarrond de procedure van collectieve schuldenregeling is gebouwd, verduidelijken.

\section{I.3 Europese context en referentiekader}

8. Wetgeving betreffende insolventie van consumenten maakt meer en meer deel uit van de Europese rechtstraditie. ${ }^{9}$ Vanuit functioneel oogpunt betreft het wetgeving die volgende kenmerken vertoont: (a) een procedure die leidt tot een gehele of gedeeltelijke bevrijding van schulden, (b) een voor particulieren toegankelijke herstelprocedure, (c) een omwille van haar geringe kostprijs laagdrempelige procedure en (d) één omvattende regeling betreffende goederen, inkomsten en passief van de schuldenaar.

Wetgevingen die aan deze functionele omschrijving voldoen, vormen als het ware een vork. Hoewel zij een aantal basiselementen gemeen hebben, zijn er ook grote verschillen. De minimale criteria waaraan zij voldoen voorzien in een nieuwe financiële start. Meestal is de toekenning van deze start niet vrijblijvend, maar verbonden aan in een plan neergelegde voorwaarden en maatregelen. Bijgevolg kan worden gesproken van een 'verdiende nieuwe start'. Deze start rehabiliteert de schuldenaar. Deze rehabilitatie kan met de kwijtschelding van (een gedeelte van) de schulden gepaard gaan. In de regel vertonen de curatieve initiatieven een voorkeur voor buitengerechtelijke regelingen. Tot slot is meestal juridische bijstand voor de schuldenaar binnen de insolventieprocedure beschikbaar. ${ }^{\text {IO }}$

9. Zie hierover U. Reifner, J. Kiesilainen, N. Huls en H. Springeneer, Consumer Overindebtedness and Consumer Law in the European Union (Final Report presented by the Institute for financial services e.v. - Erasmus University Rotterdam/School of Law - University of Helsinki/Helsinki Collegium for Advanced Studies to the Commission of the European Communities, Health and Consumer Protection Directorate-General), september 2003, I62 e.v. (elektronische versie te raadplegen op www.iaclaw.org/ Research_papers/iff_OverindebtednessandConsumerLaw.pdf (geraadpleegd op I8 augustus 2008)). Het onderzoek wijst uit dat van de 15 toenmalige lidstaten (in 2003) ro over een insolventiewetgeving voor particulieren beschikten. Vgl. de uiteenzetting van B. De Groote en K. Broeckx over 'Schuldhulpverlening in perspectief' op de sectie 'Wettelijk traject' van het 6de Jaarcongres Actualiteiten Schuldhulpverlening te Utrecht (Jaarbeurs) op I2 april 2006 (zie www.eventblogs.nl/index.php?/ weblog/comments/actuele_schuldhulpverlening_debat/ (geraadpleegd op I8 augustus 2008)).

Io. Vgl. art. I675/6, \$3 Ger. W. op grond waarvan de rechter in zijn beschikking tot toelaatbaarheid tot de collectieve schuldenregeling ambtshalve uitspraak doet over de eventuele toekenning van volledige of gedeeltelijke rechtsbijstand. 
Binnen deze Europese vork situeert zich ook de Belgische collectieve schuldenregeling. Hiernavolgend zal de procedure worden geëvalueerd door te verduidelijken of en hoe zij afstand heeft genomen van de minimale wezenskenmerken van een insolventieprocedure voor particulieren.

9. Toetssteen voor een actuele status van de Belgische (gewijzigde) collectieve schuldenregeling vormt de hierboven aangestipte studie uit 2003 met betrekking tot Consumer Overindebtedness and Consumer Law in the European Union. ${ }^{\mathrm{II}}$ Het rapport besluit het rechtsvergelijkend overzicht met de formulering van negen aanbevolen principes die iedere deugdelijke curatieve insolventieregelgeving voor consumenten tot uitdrukking zou moeten brengen.

\section{$2 \quad$ Legitieme en solidaire insolventiewetgeving voor particulieren}

Io. De belangrijkste vaststelling betreft het bestaan zelf van een wettelijke insolventieprocedure voor particulieren. Zij tilt overmatige schuldenlast boven de individuele context uit en illustreert de maatschappelijke betrokkenheid bij de problematiek en de curatieve benadering ervan.

De Belgische wetgever heeft sinds I januari 1999 zo een specifieke procedure geïntroduceerd. Het betreft de collectieve schuldenregeling. Zij vormt een onderdeel van het Gerechtelijk Wetboek. Meer in het bijzonder betreft het Titel IV van Deel V van het Gerechtelijk Wetboek. Dit deel bestrijkt de artikelen I386 tot I675/I9 en behandelt het bewarend beslag, de middelen tot tenuitvoerlegging en de collectieve schuldenregeling. ${ }^{12}$

II. Hoewel overmatige schuldenlast zich voornamelijk uit in de relatie tussen de schuldenaar en zijn schuldeisers, betreft het een maatschappelijk fenomeen. Zo is schuldenlast in veel gevallen een gevolg van overkreditering en overconsumptie. Dit leidt op zijn beurt tot (financiële) uitsluiting van de betrokken schuldenaar die op die manier kan worden gemarginaliseerd.

Tegen deze achtergrond heeft de Belgische wetgever een globale curatieve regeling uitgewerkt die tot bevrijding en financiële rehabilitatie moet leiden, waarbij de gevolgen van het aanzuiveren van de situatie van overmatige schuldenlast niet alleen

II. U. Reifner, J. Kiesilainen, N. Huls en H. Springeneer, Consumer Overindebtedness and Consumer Law in the European Union (Final Report presented by the Institute for financial services e.V. - Erasmus University Rotterdam/School of Law - University of Helsinki/Helsinki Collegium for Advanced Studies to the Commission of the European Communities, Health and Consumer Protection DirectorateGeneral), september 2003, I62 e.v. (elektronische versie te raadplegen op www.iaclaw.org/ Research_papers/iff_OverindebtednessandConsumerLaw.pdf (geraadpleegd op I8 augustus 2008)).

I2. Door deze plaats heeft de wetgever de verwevenheid tussen de executieproblematiek en het vraagstuk van de overmatige schuldenlast willen beklemtonen. In het kader hiervan moet worden opgemerkt dat de wetgever er in 2005 voor heeft gekozen om de collectieve schuldenregeling over te hevelen van de executierechter bij uitstek (de beslagrechter in de rechtbank van eerste aanleg) naar de arbeidsgerechten. Zie hierover (kritisch) K. Broeckx, B. De Groote en S. Voet, 'Grondige revisie van de collectieve schuldenregeling', T.P.R. 2007, p. I553-I558, nrs. 5-II en B. De Groote en S. Voet, 'De vernieuwde Wet op de Collectieve Schuldenregeling', P.\&B. 2007, p. I32-I34, nrs. 4-II. 
door de schuldenaar - en bij uitbreiding diens familie, zekerheidsstellers, ... - maar in meer of mindere mate ook door zijn schuldeisers worden gedragen.

Deze zogenaamde herverdeling van het passief heeft vanzelfsprekend ook een bredere maatschappelijke betekenis. Niet enkel zullen de verliezen die een schuldeiser op macroniveau maakt worden verrekend in bijvoorbeeld de kostprijs van prestaties aan andere (toekomstige) schuldenaars, er is bovendien ook sprake van een immateriële maatschappelijke kost. Het meest voor de hand liggende voorbeeld vormt de kwijtscheldbaarheid van schulden met het oog op financiële re-integratie, waarbij de wetgever het algemene beginsel dat verbintenissen moeten worden uitgevoerd, relativeert. Een ander voorbeeld vormt de bij de wijziging van december 2005 geïntroduceerde prioritaire betaling van schulden om de schuldenaar een menswaardig bestaan te garanderen. ${ }^{13}$ De maatschappelijke betekenis bestaat in het feit dat de last van de aanzuivering, los van het systeem van de voorrechten en zekerheden, niet noodzakelijk evenredig wordt verdeeld tussen de betrokken schuldeisers. Tevens is hier sprake van de introductie van een nieuw concept dat uiting geeft aan de sociale visie die de wetgever in de belangenafweging tot uitdrukking wil brengen, namelijk de prioritaire betaling met het oog op de menswaardigheid, dat conflicteert met het concept van de paritas creditorum.

I2. De toegang tot de procedure is breed. Naast een objectieve voorwaarde, die erin bestaat dat er sprake moet zijn van overmatige schuldenlast (i.c. het niet in staat zijn om op duurzame wijze zijn opeisbare of nog te vervallen schulden te betalen), moet aan een subjectieve voorwaarde voldaan zijn. De schuldenaar mag niet kennelijk zijn onvermogen hebben bewerkstelligd. Een gebrek aan (contractuele) goede trouw belet de toegang tot de procedure bijgevolg niet. ${ }^{\mathrm{I}}$ Het verstrekken van onjuiste of onvolledige informatie bij het aangaan van kredietovereenkomsten is geen voldoende reden om de schuldenaar de toegang tot de collectieve schuldenregeling te ontzeggen. Dit belet niet dat begeleidende omstandigheden bij het verstrekken van onjuiste of onvolledige informatie de beoordeling van de subjectieve toelaatbaarheidsvoorwaarde kunnen beïnvloeden.

Om van de procedure te worden uitgesloten moet dus veeleer het (bewuste) opzet om zich onvermogend te maken aanwezig zijn. De schuldenaar moet bewust ten nadele van zijn schuldeisers hebben gehandeld. Om dit vast te stellen mag men zich niet laten leiden door een loutere a posteriori beoordeling. De omstandigheid dat de insolventie aan de schuldenaar zelf te wijten is, sluit hem niet noodzakelijk van de procedure uit.

Sommige rechtspraak heeft de subjectieve toelaatbaarheidsvoorwaarde ruimer geïnterpreteerd dan het opzettelijk ten nadele van zijn schuldeisers handelen. Zo leiden een onverantwoord bestedingsgedrag, herhaaldelijke verkeersinbreuken of

I3. Zie art. I675/I0, §4, eerste lid, in fine Ger. W. (minnelijke aanzuiveringsregeling) en art. I675/I2, §5 Ger. W. (gerechtelijke aanzuiveringsregeling).

I4. Zie hierover E. Dirix en A. De Wilde, 'Materieelrechtelijke aspecten van de collectieve schuldenregeling', in E. Dirix en P. Taelman (eds.), Collectieve schuldenregeling in de praktijk, Antwerpen, Intersentia, I999, nr. I7 en B. Wylleman en E. Van Acker, Praktische gids voor de schuldbemiddelaars, Mechelen, Kluwer, 2006, nr. 22. 
zware misdrijven wel eens tot weigering van de procedure. ${ }^{15}$ Hoewel de aanzuivering van overmatige schuldenlast, eerder dan de oorsprong ervan, centraal heeft gestaan bij de redactie van de procedure, moet worden opgemerkt dat deze strengere interpretatie ingegeven kan zijn door de zorg om de maatschappelijke aanvaardbaarheid van de procedure van collectieve schuldenregeling. Deze is niet gebaat bij een beeldvorming dat maatschappelijk onverantwoord gedrag onvoldoende krachtdadig afkeurt. Anderzijds is overmatige schuldenlast, ongeacht zijn oorsprong, een realiteit en is de samenleving niet gebaat bij het uitblijven van financieel herstel door middel van een zo groot mogelijke aanzuivering.

Misschien is het wenselijk bij de interpretatie van de subjectieve toelaatbaarheidsvoorwaarde te neigen in de richting van een positief antwoord op de door Dirix en De Wilde in de eerste commentaren op de wet gestelde vraag of het onderscheid tussen 'goede trouw' en het in art. $1675 / 2$ Ger. W. opgenomen criterium niet veeleer een spel van woorden is, waarbij deze begrippen in de praktijk niet zo sterk van elkaar moeten verschillen. ${ }^{\mathrm{I} 6}$

I3. Ongeacht de houding die wordt aangenomen bij de beoordeling van de subjectieve toelaatbaarheidsvoorwaarde, zijn situaties te betreuren waarin een schuldenaar tot de procedure wordt toegelaten, loyaal aan de aanzuiveringsregeling meewerkt, doch aan het einde ervan niet volkomen bevrijd wordt. Dit doet zich vooral voor indien de aanzuiveringsregeling de schuldenaar niet toelaat zijn schulden terug te betalen en deze niet worden kwijtgescholden. In dit kader moet de discussie over de kwijtscheldbaarheid van geldboetes worden vermeld. In zoverre zij geen beletsel blijken om tot de collectieve schuldenregeling te worden toegelaten, vormen zij dit wel voor de aanzuivering. ${ }^{17}$

Bij uitbreiding kan de vraag worden gesteld of de niet-kwijtscheldbaarheid van de uitdrukkelijk in art. 1675/13 Ger. W. als zodanig aangemerkte schulden niet ter discussie kan worden gesteld. Indien zij binnen de aanzuiveringsregeling niet kunnen worden terugbetaald, rijst immers de vraag in hoeverre het perspectief op latere terugbetaling opweegt tegen het beletsel dat zij vormen voor een nieuwe financiële start. ${ }^{\mathrm{I}}$

Ook het feit dat het ontbreken van afbetalingsmogelijkheden de toelaatbaarheid niet in de weg mag staan, illustreert het problematisch karakter van de verhouding tussen de toelaatbaarheidsvoorwaarde en de aanzuiveringsmogelijkheden. Precies om die reden heeft de wetgever in december 2005 de figuur van de totale kwijtschelding geïntroduceerd. Het Grondwettelijk Hof wees al eerder op de ongrondwettelijke ongelijkheid die zou bestaan indien art. I675/13, §I Ger. W. op die manier zou worden geïnterpreteerd dat omwille van het slechts gedeeltelijke karakter van de in

I5. Zie hierover E. Dirix, 'Boeven en schuldsanering' (noot onder Antwerpen II januari 2006), R.W. 2007-2008, III5-III7 en E. Dirix B. Wylleman en E. Van Acker, Praktische gids voor de schuldbemiddelaars, Mechelen, Kluwer, 2006, nr. 23 en verwijzingen aldaar.

I6. E. Dirix en A. De Wilde, 'Materieelrechtelijke aspecten van de collectieve schuldenregeling', in E. Dirix en P. Taelman (eds.), Collectieve schuldenregeling in de praktijk, Antwerpen, Intersentia, I999, nr. I7.

17. Zie uitvoerig over deze problematiek B. De Groote, 'Bedenkingen bij het begrip "misdrijf" in het licht van de niet-kwijtscheldbaarheid van de vergoeding van lichamelijke schade' (bedenkingen bij arrest nr. I75/2006 van 22 november 2006 van het Grondwettelijk Hof), te verschijnen in Jaarboek kredietrecht en collectieve schuldenregeling 2007. 
dit artikel bedoelde kwijtschelding, precies de persoon die definitief en totaal onvermogend is de mogelijkheid zou worden ontzegd om een gerechtelijke aanzuiveringsregeling te genieten. ${ }^{\mathrm{I} 9}$ Bijgevolg kan ook een totaal en definitief onvermogend lijkende persoon de toegang niet worden geweigerd.

I4. De subjectieve voorwaarde wordt marginaal getoetst. Het toelaatbaarheidsverzoek is trouwens eenzijdig en moet binnen acht dagen worden beoordeeld. Indien echter in de loop van de procedure blijkt dat de schuldenaar - ook door feiten die de toelaatbaarverklaring zijn vooraf gegaan ${ }^{20}$ - zijn onvermogen heeft bewerkt, kan de collectieve schuldenregeling worden herroepen. De feiten die tot de herroeping leiden kunnen bij de marginale controle naar aanleiding van de toelaatbaarverklaring aan de oppervlakte zijn gebleven. Het is bijgevolg mogelijk dat een loyaal meewerkende, tot de procedure toegelaten, schuldenaar met een herroeping wordt geconfronteerd. Deze sanctie is enerzijds begrijpelijk, maar illustreert anderzijds de pijnlijke incongruentie tussen de beoordeling van het 'bewerken van zijn onvermogen' naar aanleiding van de toelaatbaarverklaring en bij herroeping.

\section{$3 \quad$ Bevrijdingsregeling}

I5. Het tweede principe betreft de bevrijding die, afhankelijk van de individuele mogelijkheden tot terugbetaling, geheel of gedeeltelijk kan zijn. Dit impliceert dat de bevrijding afhankelijk zal zijn van het naleven van een aanzuiveringstraject dat een zo groot mogelijke terugbetaling van de schulden tot doel heeft.

Een aanzuiveringstraject kan ook verder gaan dan een loutere terugbetaling. Het kan begeleidende maatregelen bevatten die een structurele aanpak van de schuldenproblematiek en zijn oorzaken tot doel hebben. Deze kunnen de schuldenaar - door doorgedreven advies, (hulp bij) het beheer van zijn budget enz. - helpen bij het creëren van randvoorwaarden die het succesvol nemen van een nieuwe start begunstigen. Hoewel dit stigmatiserend kan klinken, betreft het als het ware een proces van

I8. Sommige rechtspraak laat de schuldenaar niet toe tot de procedure bij gebrek aan procedurele goede trouw indien de schuldenlast voor het grootste deel uit niet-kwijtscheldbare schulden bestaat terwijl geen concrete suggestie wordt gedaan over de wijze waarop deze zou kunnen worden voldaan in het kader van de collectieve schuldenregeling (B. Wylleman en E. Van Acker, Praktische gids voor de schuldbemiddelaars, Mechelen, Kluwer, 2006, nr. 24, verwijzend naar Antwerpen 6 maart 200I, R.W. 200I-2002, 783 en Brussel 8 juni 2000, J.L.M.B. 200I, 909). De vraag rijst echter of het probleem dat deze rechtspraak aanstipt niet eerder verband houdt met de incongruentie tussen de toelaatbaarheidsvoorwaarden en de beperkingen van de beschikbare aanzuiveringstechnieken, dan met een gebrek aan procedurele goede trouw. Deze laatste betreft de oprechtheid van de schuldenaar bij het indienen van het verzoekschrift, alsook bij de uitwerking en naleving van het plan. Deze onontbeerlijke voorwaarde wordt gesanctioneerd met herroeping en ligt in het verlengde van het feit dat de collectieve schuldenregeling een gunstmaatregel is.

I9. Arbitragehof nr. I8/2003, 30 januari 2003, A.A. 2003, I67; B.S. 20 maart 2003; J.L.M.B. 2003, 268; Jaarboek Kredietrecht 2002, 558; R.W. 2003-04, I30, noot; T.B.B.R. 2003, 249 en T.G.R. 2003, 26. In dezelfde zin Arbitragehof nr. 38/2003, 3 april 2003, A.A. 2003, 47I; B.S. 27 juni 2003; D.C.C.R. 2004, 32, noot B. De Groote en Jaarboek Kredietrecht 2003, 469.

20. Zie E. Dirix en A. De Wilde, 'Materieelrechtelijke aspecten van de collectieve schuldenregeling', in E. Dirix en P. Taelman (eds.), Collectieve schuldenregeling in de praktijk, Antwerpen, Intersentia, I999, nr. 92 en B. De Groote, De collectieve schuldenregeling, Antwerpen, Kluwer, I999, p. I32-I35. 
financiële en socio-economische heropvoeding. Deze aanvullende voorwaarden hebben niet enkel tot doel de weerbaarheid van de schuldenaar te vergroten. $\mathrm{Zij}$ komen ook de schuldeisers ten goede en dragen bij tot de maatschappelijke aanvaardbaarheid van de procedure. Zij onderstrepen dat de procedure geen vrijgeleide mag vormen voor onverantwoorde schuldenaars. Anderzijds mogen de voorwaarden en hun duur niet van die aard zijn dat zij er enkel toe strekken tegemoet te komen aan gevoelens van wraak of afgunst bij medeburgers. De voorwaarden mogen schuldenaars niet nodeloos (lang) verhinderen opnieuw op volwaardige wijze socio-economisch te participeren en bij te dragen aan de markteconomie. Niet zelden hebben zij trouwens al een moeilijk proces doorgemaakt alvorens zij verzoeken om tot een aanzuiveringsprocedure te worden toegelaten.

Bij absoluut onvermogen tot aanzuivering dringt zich in voorkomend geval een totale kwijtschelding van schulden op. Dit kan gebeuren onder de vorm van een zeropayment-plan waarbij de begeleidende maatregelen de essentie vormen. Dergelijk plan laat toe de situatie van de schuldenaar beter op te volgen en komt tegemoet aan de situatie van de meest onfortuinlijke schuldenaars die het meest baat hebben bij een 'fresh start'. Zo wordt vermeden dat zij uit de procedure worden gesloten terwijl deze precies tot hun rehabilitatie zou moeten leiden.

I6. Ook met de tweede toetssteen is de Belgische collectieve schuldenregeling compatibel. De wetgeving heeft uitdrukkelijk tot doel de financiële toestand van de schuldenaar $^{2 \mathrm{I}}$ te herstellen. Dit zal in beginsel gebeuren door het naleven van een (minnelijke of gerechtelijke) aanzuiveringsregeling ${ }^{22}$ die voorziet in een terugbetaling van de schulden. Indien dit laatste, in het licht van de gewaarborgde menswaardigheid, ${ }^{23}$ onmogelijk is, dringt zich een kwijtschelding op. ${ }^{24}$

Vóór de wetswijziging van december 2005 kon de rechter enkel een gedeeltelijke kwijtschelding opleggen. Hierin heeft de Belgische wetgever, onder impuls van de rechtspraak van het Grondwettelijk Hof (voormalig Arbitragehof) verandering gebracht. ${ }^{25}$ Meer in het bijzonder stelde het Grondwettelijk Hof vast dat het slechts

2I. I.c. een natuurlijke persoon (niet-handelaar) die niet in staat is om, op een duurzame wijze, zijn opeisbare of nog te vervallen schulden te betalen (art. $1675 / 2$, eerste lid Ger. W.).

22. De schuldenaar stelt in de eerste plaats, onder toezicht van de rechter, zijn schuldeisers een minnelijke aanzuiveringsregeling voor. Dit minnelijke aanzuiveringsplan wordt opgesteld door de schuldbemiddelaar. Indien dit niet lukt, zal de rechter een gerechtelijke aanzuiveringsregeling opleggen. De inhoud van de in de minnelijke regeling opgenomen aanzuiveringsmaatregelen is in beginsel vrij. De regeling vindt steun in de wilsautonomie die de er unaniem mee instemmende betrokken partijen uitoefenen. De inhoud van de gerechtelijke regeling is daarentegen wettelijk bepaald.

23. Zoals grondwettelijk gewaarborgd in art. 23 gec. G.W.

24. Zie art. I675/12, I675/I3 en I675/13 bis Ger. W.

25. Arbitragehof nr. 35/200I, I3 maart 200I, A.A. 200I, 529; A.J.T. 200I-02, 316; B.S. 6 juni 200I; J.L.M.B. 200I, 899, noot G. De Leval; Jaarboek Kredietrecht 2000, 308 en R.W. 200I-02, 1093, noot E. Dirix. Vgl. Arbitragehof nr. I8/2003, 30 januari 2003, A.A. 2003, I67; B.S. 20 maart 2003; J.L.M.B. 2003, 268; Jaarboek Kredietrecht 2002, 558; R.W. 2003-04, I30, noot; T.B.B.R. 2003, 249 en T.G.R. 2003, 26 en Arbitragehof nr. 38/2003, 3 april 2003, A.A. 2003, 47I; B.S. 27 juni 2003; D.C.C.R. 2004, 32, noot B. De Groote en Jaarboek Kredietrecht 2003, 469. Zie over deze problematiek eveneens B. De Groote, 'Tien knelpunten inzake collectieve schuldenregeling', in G. Martyn (ed.), Beslag en collectieve schuldenregeling (Orde van advocaten - departement Vorming en beroepsopleiding), Gent, Larcier, 2004, p. 80-84 en verwijzingen aldaar. 
gedeeltelijke karakter van de kwijtschelding een ongeoorloofde discriminatie kan inhouden in zoverre zij precies de meest onfortuinlijke schuldenaar, bij wie de kans op marginalisering het grootst is, de kans op een 'fresh start' zou ontnemen.

Om die reden heeft de wetgever in art. $1675 / 13$ bis Ger. W. de totale kwijtschelding van schulden geïntroduceerd. De schuldbemiddelaar neemt hiertoe het initiatief indien blijkt dat geen enkele minnelijke of gerechtelijke aanzuiveringsregeling mogelijk is omdat de schuldenaar over onvoldoende middelen beschikt. Indien de rechter de visie van de schuldbemiddelaar, die erin bestaat dat geen middelen voorhanden zijn om in het kader van een aanzuiveringsplan onder de schuldeisers ter delging van de schuld te worden uitgedeeld, bijtreedt, kan hij beslissen tot een snelle liquidatie. Zonder dat een aanzuiveringsregeling moet worden opgelegd, aan het einde waarvan de kwijtschelding verworven wordt, kan hij een totale kwijtschelding van schulden toestaan. Om de kansen op structureel herstel van de financiële situatie van de schuldenaar te verhogen kan hij de beslissing tot kwijtschelding van schulden gepaard laten gaan met begeleidingsmaatregelen. De niet-naleving ervan kan, indien dit aan de schuldenaar toe te schrijven is, leiden tot het verlies van het voordeel van de kwijtschelding.

Dat bijvoorbeeld ook fiscale schulden, waarvan het karakter als het ware bij uitstek maatschappelijk is, niet aan deze kwijtschelding ontsnappen, illustreert andermaal het globale karakter van overmatige schuldenlast en de wijze waarop de collectieve schuldenreling deze aanpakt. De discussie over de al dan niet kwijtscheldbaarheid van geldboetes ${ }^{26}$ verduidelijkt hoe de legitimiteit van curatieve maatregelen minder vanzelfsprekend wordt naarmate de - hoewel soms veeleer symbolische - maatschappelijke kost van de aanzuiveringsregeling toeneemt.

\section{$4 \quad$ Voorkeur voor buitengerechtelijke aanpak}

I7. Op de derde plaats komt de voorkeur voor informele oplossingen en buiten de rechtbank tot stand gekomen akkoorden tussen de schuldenaar en zijn schuldeisers. Deze blijken niet alleen voor de schuldenaar, maar ook voor zijn schuldeisers, tot de beste resultaten te leiden. De vrijwilligheid kan tevens de betrokkenheid versterken. De belanghebbende partijen stellen zich constructiever op waardoor de betrokkenheid verhoogt. Daarenboven is de kostprijs, onder meer voor de maatschappij, lager dan bij een gerechtelijke oplossing. De aanpak is discreet en zeer flexibel, waardoor gemakkelijk op externe factoren kan worden ingespeeld. Het plan kan echt op maat worden gemaakt en ook het lot van zekerheidsstellers en medeschuldenaars regelen.

26. Zie hierover B. De Groote, 'Het pijnlijke spanningsveld tussen de toelaatbaarheidsvoorwaarden en de kwijtscheldbaarheid van schulden in de collectieve schuldenregeling' (commentaar bij Beslagr. Hasselt 8 december 2000), Jaarboek kredietrecht en collectieve schuldenregeling 2001 - Annuaire juridique du crédit et du règlement collectif de dettes 2001, Charleroi, L'observatoire du crédit et de l'endettement, 2002, 327-332 en verwijzingen aldaar. Over de invloed van strafrechtelijke geldboeten op de toelaatbaarheid en over hun kwijtscheldbaarheid zie K. Broeckx en B. De Groote, 'De particuliere schuldenaar in de collectieve schuldenregeling: toelaatbaarheidsvoorwaarden', in XXXIste P.U.C. Willy Delva, Insolventierecht 2004-2005, Mechelen, Kluwer, 2006, 37-40; K. Broeckx en B. De Groote, 'Collectieve schuldenregeling in de praktijk', in E. Dirix en P. Taelman (eds.), Beslag- en executierecht. Naar een collectief beslagrecht, Antwerpen, Intersentia, 2001, 202 en K. Loontjens, 'Enkele praktische problemen in verband met de collectieve schuldenregeling', in G. Martyn (ed.), Beslag en collectieve schuldenregeling, Gent, Larcier, 2004, 103-105. 
I8. In de Belgische procedure van collectieve schuldenregeling zit een minnelijke fase vervlochten. Zij geniet de voorkeur. De bemiddelaar beschikt over een, weliswaar verlengbare, termijn van zes maanden om de partijen te verzamelen rond een minnelijk aanzuiveringsplan. In overeenstemming met art. I675/Io Ger. W. neemt de rechter akte van het gesloten akkoord. Pas als de bemiddelaar er niet in slaagt unanimiteit te bereiken, kan hij het dossier overmaken aan de rechter die een gerechtelijke aanzuiveringsregeling kan opleggen of in voorkomend geval kan besluiten tot een in art. $1675 / 13$ bis Ger. W. bedoelde totale kwijtschelding van de schulden.

Hoewel de minnelijke fase de wilsautonomie van de betrokken partijen als grondslag heeft, vertoont zij niettemin een hybride karakter in zoverre zij een onderdeel is van een door de rechter bewaakte procedure. Hoewel deze buitengerechtelijke aanpak, omwille van het akkoord van de betrokken partijen, een breder gamma aan aanzuiveringsmogelijkheden biedt die zich bovendien over een langere periode kunnen uitstrekken, schuilt in dit akkoord en de mogelijkheid het door een veto te blokkeren, eveneens de Achilleshiel ervan. Daarenboven moet het bezwaar tegen het door de schuldbemiddelaar ontworpen aanzuiveringsplan niet van een tegenvoorstel vergezeld zijn. Het gaat met andere woorden niet om een constructieve motie van wantrouwen. In de praktijk heeft de figuur van het rechtsmisbruik de minnelijke fase versterkt. Het laat toe misgebruik van het vetorecht te overrulen. ${ }^{27}$

In 2005 heeft de wetgever dit probleem structureel willen aanpakken. In art. I675/ Io, §3 bis Ger. W. werd bepaald dat alle schulden, ongeacht hun aard, minnelijk kunnen worden kwijtgescholden. Meteen werd de fiscale administratie ${ }^{28}$ en de sociale zekerheid een wettelijke basis gegeven om in te stemmen met minnelijke aanzuiveringsregelingen die een kwijtschelding van schulden in hoofdsom inhouden. ${ }^{29}$ Over de (minnelijke) kwijtscheldbaarheid van penale boetes blijft de controverse, die het gevolg is van de in art. IIo gec. G.W. bedoelde bevoegdheid van de Koning om amnestie te verlenen, echter bestaan. ${ }^{30}$

27. Zie hierover onder meer B. De Groote, 'Het keurslijf van de gerechtelijke aanzuiveringsregeling na betwistbaar verzet tegen het minnelijk ontwerp: denksporen' (noot onder Beslagr. Aarlen 26 oktober I999), Jaarboek kredietrecht en collectieve schuldenregeling I999, 4I7-I34; B. De Groote, 'Actuele knelpunten betreffende collectieve schuldenregeling', in G. Martyn (ed.), Beslag en collectieve schuldenregeling, Gent, Larcier, 2004, 29 e.v. en K. Loontjens, 'Enkele praktische problemen in verband met de collectieve schuldenregeling', in G. Martyn (ed.), Beslag en collectieve schuldenregeling, Gent, Larcier, 2004, IIO-II2.

28. Die op grond van art. 172 , lid 2 gec. G.W. elk minnelijk plan dat een kwijtschelding van schulden in hoofdsom inhield, kelderde.

29. B. Vanermen, 'De belastingontvangers kunnen weldra kwijtschelding van fiscale schulden aanvaarden', R.W. 2005-06, I292-I299.

30. Zie hierover: B. De Groote, 'Het pijnlijke spanningsveld tussen de toelaatbaarheidsvoorwaarden en de kwijtscheldbaarheid van schulden in de collectieve schuldenregeling' (commentaar bij Beslagr. Hasselt 8 december 2000), in X., Jaarboek kredietrecht en collectieve schuldenregeling $2001-$ Annuaire juridique du crédit et du règlement collectif de dettes 2001, Charleroi, L'observatoire du crédit et de l'endettement, 2002, 327-332 en verwijzingen aldaar; A. De Wilde en P. Helsen, 'Kan de gerechtelijke collectieve schuldenregeling leiden tot de kwijtschelding van strafrechtelijke geldboeten?', Jura Falc. I999-2000, 535-544 en K. Loontjens, 'Enkele praktische problemen in verband met de collectieve schuldenregeling', in G. Martyn (ed.), Beslag en collectieve schuldenregeling, Gent Larcier, 2004, 103-I05. 
In de rand hiervan moet worden aangestipt dat vrijwilligheid, voornamelijk in hoofde van de schuldenaar, een doorslaggevende rol speelt bij de collectieve schuldenregeling als dusdanig. Anders dan bij het faillissement moet het initiatief tot de procedure immers uitgaan van de schuldenaar. Deze zwakte van de procedure is tegelijk een essentiële sterkte ervan. Zij kan immers het engagement van de schuldenaar verhogen, wat belangrijk is omwille van de aanzienlijke impact van de procedure op de schuldenaar en zijn gezin. Hoewel de wetgever dit niet uitdrukkelijk heeft voorzien, wordt precies daarom gemakkelijk gevolg gegeven aan het verzoek van de schuldenaar om de procedure te verlaten. Daartegenover staat de vraag of men de draagwijdte van de impact van de schuldenlast, de dreigende marginalisering en het initiatief tot de curatieve procedure enkel van de schuldenaar mag laten afhangen. Omwille van de zorg om de noodzakelijke medewerking van de schuldenaar, moet deze bij een gerechtelijke aanzuivering verzoeken om een kwijtschelding van kapitaalschulden. De voorwaarden waaraan zij, naast het doorlopen van de aanzuiveringsregeling, verbonden is, zoals de verkoop van de voor beslag vatbare activa, zijn immers ingrijpend en vergen sterk engagement. Hoewel voor een totale kwijtschelding zonder aanzuiveringsregeling dezelfde randvoorwaarden gelden, is het initiatief van de schuldenaar niet nodig. Dit zou kunnen betekenen dat de wetgever hun rol in deze context, waarbij geen sprake is van een aanzuiveringsregeling, minder ingrijpend acht of niet laat opwegen tegen het - naar onze mening nochtans in alle situaties van structurele overmatige schuldenlast prominent aanwezige - belang van mogelijk financieel herstel.

\section{$5 \quad$ Gerechtelijke procedure}

I9. Omdat een vrijwillige oplossing niet steeds kan worden bereikt, moet een rechterlijke procedure voorhanden zijn als vangnet. Deze procedure leidt tot een rechterlijke bevrijding. Zij houdt, zonder nodeloos complex te worden, voldoende garanties in voor de belangen van zowel de schuldenaar als zijn schuldeisers. ${ }^{3 \mathrm{I}}$

20. In de Belgische collectieve schuldenregeling is, voor het geval een vrijwillige oplossing uitblijft, een gerechtelijke procedure voorzien.

Opnieuw moet worden opgemerkt dat de collectieve schuldenregeling zelf, niettegenstaande zij tot een minnelijke aanzuiveringsregeling kan leiden, eigenlijk een gerechtelijke procedure is. $\mathrm{Zij}$ wordt trouwens met rechterlijke tussenkomst op de

3I. U. Reifner, J. Kiesilainen, N. Huls, H. Springeneer, Consumer Overindebtedness and Consumer Law in the European Union (Final Report presented by the Institute for financial services e.V. - Erasmus University Rotterdam/School of Law - University of Helsinki/Helsinki Collegium for Advanced Studies to the Commission of the European Communities, Health and Consumer Protection DirectorateGeneral), september 2003, 25I, elektronische versie verkrijgbaar via U. Reifner, J. Kiesilainen, N. Huls en H. Springeneer, Conrumer Overindebtedness and Consumer Law in the European Union (Final Report presented by the Institute for financial services e.V. - Erasmus University Rotterdam/School of Law - University of Helsinki/Helsinki Collegium for Advanced Studies to the Commission of the European Communities, Health and Consumer Protection Directorate-General), september 2003, 25I (elektronische versie te raadplegen op www.iaclaw.org/Research_papers/iff_Overindebt ednessandConsumerLaw.pdf (geraadpleegd op I8 augustus 2008)). 
sleutelmomenten en onder rechterlijk toezicht afgewikkeld. Zij onderscheidt zich van buitengerechtelijke vormen van schuldbemiddeling, zoals als bedoeld in de wet op het consumentenkrediet. ${ }^{2}$

Een belangrijke eigenschap van de gerechtelijke procedure sensu lato is het feit dat zij zich over alle schuldeisers uitstrekt. Schuldeisers kunnen zich wel verzetten tegen het ontwerp van minnelijke aanzuiveringsregeling, maar kunnen zich niet aan de procedure onttrekken. Bovendien moeten zij voor ogen houden dat hun verzet noodgedwongen tot een gerechtelijke aanzuiveringsregeling zal leiden die hen, door het beperkter gamma aan aanzuiveringsmogelijkheden en de looptijdbeperking, niet noodzakelijk in een gunstiger aanzuiveringspositie zal brengen.

Bij een gerechtelijke procedure sensu stricto legt de rechter een voor alle betrokkenen bindend aanzuiveringsplan op, waarbij hij een globale oplossing voor de situatie van overmatige schuldenlast oplegt. Het aanzuiveringsritme, het aan te zuiveren en kwijt te schelden bedrag, de te gelde te maken goederen en de verdeling van hun opbrengst, de begeleidende maatregelen, enz. maken van deze oplossing deel uit. Los van een aanzuiveringsplan kan de rechter, bij totale ontoereikendheid van middelen, een voor alle schuldeisers bindende totale kwijtschelding van schulden opleggen. Deze kwijtschelding is niet van de instemming van de schuldeisers afhankelijk. Enkel niet voor kwijtschelding vatbare schulden ontsnappen hieraan. ${ }^{33}$

Een ander illustratie van het belang van de gerechtelijke aanpak is het feit dat de (nochtans ingelichte) schuldeiser die niet tijdig en correct aangifte heeft gedaan van zijn schuldvordering, geacht wordt afstand te hebben gedaan van zijn vordering. ${ }^{34}$ Het globale karakter van de regeling en haar aanzuiverend effect zijn hem niettemin tegenwerpelijk zodat hij zich ook buiten en na de collectieve schuldenregeling niet tot de schuldenaar kan wenden. Evenmin mogen zij zich nog verhalen op de personen die voor de schuldenaar een persoonlijke zekerheid hebben gesteld. De enige uitzondering hierop vormt de hypothese waarin de schuldenaar een aanzuiveringsregeling wordt geweigerd of bij herroeping.

2I. Het geschetste globale karakter van de gerechtelijke regeling sensu lato steunt op de veronderstelling dat de schuldeisers van de regeling op de hoogte zijn. Hierin schuilt een pijnpunt. De wetgever heeft de efficiëntie van een algemeen publiciteitsmechanisme afgewogen tegen het eraan verbonden risico op stigmatisering en gemeend minstens even afdoende informatie over de schuldeisers te kunnen verkrijgen bij de schuldenaar. Deze moet in zijn toelaatbaarheidsverzoek zijn financiële situatie, met inbegrip van zijn passief, immers omstandig schetsen en bijgevolg zijn

32. Zie art. $\mathrm{I}, \mathrm{I}_{3}^{\circ}$ en art. 67 van de wet van $\mathrm{I} 2$ juni I99I op het consumentenkrediet (B.S. 9 juli I99I, err. B.S. 6 augustus I99I).

33. Art. $\mathrm{I}_{675 / 13}, \$_{3}$ Ger. W.

34. De schuldeisers die de schuldenaar in het verzoekschrift heeft opgenomen, worden uitgenodigd aangifte te doen van hun schuldvordering(en). Indien zij stilzitten of niet zijn opgenomen in het verzoekschrift, worden zij door de schuldbemiddelaar overeenkomstig art. I675/9, §3 Ger. W. herinnerd door middel van een ter post aangetekende brief met ontvangstbewijs. Zij krijgen hierbij vijftien dagen de tijd om alsnog aangifte te doen. Indien zij dit niet doen worden zij geacht van hun vordering afstand te doen. 
schuldeisers opsommen opdat deze van de samenloop op de hoogte zouden kunnen worden gebracht.

Bij nalatigheid van de schuldenaar, waarvan de kwaadwilligheid impliceert dat hij zich niet te goeder trouw in de procedure engageert, beschikt de rechter over de mogelijkheid de procedure te herroepen. ${ }^{35}$ Dit sanctiemechanisme verduidelijkt hoe de gerechtelijke procedure de vrijblijvendheid van het engagement beperkt. Tegelijk laat de rechterlijke tussenkomst toe om bij gewijzigde omstandigheden de globale regeling, op voor alle betrokkenen bindende wijze, bij te sturen. ${ }^{36}$ Dit kan zich bijvoorbeeld voordoen bij het opduiken van nieuwe schuldeisers of onverwachte onkosten.

\section{Aandacht voor de zekerheidsstellers}

22. Ook aan het lot van de zekerheidsstellers moet aandacht worden besteed. Immers, wie een zekerheid of een hypotheek heeft verleend, dreigt bij overmatige schuldenlast van de schuldenaar zelf in financiële moeilijkheden te komen. De schuldeiser zal immers bij hem komen aankloppen. De bescherming tegen uitvoeringsmaatregelen die de insolventieprocedure aan de hoofdschuldenaar verleent, komt de zekerheidssteller meestal niet ten goede. Naar analogie geldt ook de bevrijding - in het bijzonder in het raam van een gerechtelijke procedure - van de schuldenaar niet voor de zekerheidssteller. Aldus ontstaat een kettingeffect, waaruit een sneeuwbal aan overmatige schuldenlast kan voortvloeien.

23. De Belgische wetgever, die de wettelijke lacune met de wetswijziging van 2005 oploste, heeft zich sterk geïnspireerd op het lot van de persoonlijke zekerheidssteller in de faillissementsprocedure, zoals uitgewerkt in de faillissementswet ${ }^{37}$ en de rechtspraak van het Grondwettelijk Hof. ${ }^{38}$

De bescherming van de persoonlijke zekerheidssteller is van tweeërlei aard. ${ }^{39}$ In de eerste plaats betreft zij de bevrijding van de zekerheidssteller. In de tweede plaats betreft zij de bescherming van de zekerheidssteller tegen uitvoeringsmaatregelen

35. Art. I675/15 Ger. W.

36. Volgens art. I675/I4, \$2, derde lid Ger. W. kan de zaak door een eenvoudige schriftelijke verklaring opnieuw aan de rechter worden voorgelegd bij moeilijkheden die de uitwerking of de uitvoering van de regeling belemmeren of wanneer nieuwe feiten zich voordoen terwijl de regeling opgesteld wordt of die feiten de aanpassing of de herziening van de regeling rechtvaardigen.

37. Art. 72 bis en art. 72 ter Faill. W. Voor een bespreking hiervan zie B. Mailleux, 'Bevrijding kosteloze borg', NjW 2005, 938-942; M. Vanmeenen, 'Wijziging van de faillissementswet. De nieuwe regeling inzake de bevrijding van persoonlijke zekerheidstellers en de verschoonbaarheid', T.B.H. 2005, 886-888 en M. Vanmeenen, 'De verschoonbaarheid - Het Arbitragehof hakt de knopen door' (noot onder Arbitragehof II4/2004 30 juni 2004), R.W. 2004-05, 666-670.

38. Zie hierover in extenso K. Broeckx, B. De Groote en S. Voet, 'Grondige revisie van de collectieve schuldenregeling', T.P.R. 2007, p. 1585-I599, nrs. 49-63. Het is zijn arrest van 28 maart 2002 (nr. 69/2002) dat de kiem voor de wetswijziging 2005 ligt ((Arbitragehof, nr. 69/2002, 28 maart 2002 A.A. 2002, 83I; B.S. 20 juni 2002; J.L.M.B. 2002, 808; Jaarboek Kredietrecht 2002, I90; R.W. 2002-03, 457, noot C. Lebon en T.B.H. 2002, 437).

39. Art. I675/r6bis Ger. W. De wetgever beoogt met het begrip persoonlijk zekerheid ook de in art. I2I6 B.W. bedoelde medeschuldenaars (Parl. St. Kamer 2003-2004, nr. I309/00I, 24). 
van de schuldeiser in afwachting van uitsluitsel over de bevrijding van de zekerheidssteller.

24. De Belgische wetgever maakt een onderscheid tussen de minnelijke en de gerechtelijke aanzuiveringsregeling.

De wetgever gaat ervan uit dat de minnelijke kwijtschelding ten gunste van de hoofdschuldenaar geen tot de persoon van deze hoofdschuldenaar beperkte gunst is. ${ }^{4^{\circ}} \mathrm{Zij}$ komt ook de persoonlijke zekerheidssteller ten goede. Om te vermijden dat de zekerheidssteller in afwachting van duidelijkheid over de minnelijke fase, die het lot van laatstgenoemde kan beïnvloeden, door een schuldeiser zou worden aangesproken, heeft de Belgische wetgever de middelen van tenuitvoerlegging die strekken tot de betaling van een geldsom ook geschorst ten aanzien van de borg. De wetgever heeft hierbij tot doel de schorsing te handhaven tot duidelijkheid bestaat over het lot van de minnelijke fase. ${ }^{4}{ }^{\mathrm{I}}$

De Belgische wetgever is van oordeel dat een gerechtelijke aanzuiveringsregeling, naar analogie van de verschoonbaarheid in het faillissementsrecht, de zekerheidssteller niet ten goede komt. Nochtans doet het gerechtelijk karakter van de kwijtschelding geen afbreuk aan de schrijnende situatie waarin de zekerheidssteller zich ten gevolge van het financieel onevenwicht van de hoofdschuldenaar kan bevinden.

Om die reden laat het nieuwe art. $1675 / \mathrm{r} 6$ bis Ger. W. de rechter toe een natuurlijke persoon die kosteloos een persoonlijke zekerheid heeft gesteld ten behoeve van de schuldenaar geheel of gedeeltelijk te bevrijden. De zekerheidssteller verkrijgt de bevrijding niet indien hij bedrieglijk zijn onvermogen heeft georganiseerd. Bovendien is de bevrijding afhankelijk van het bestaan van onevenredigheid tussen de verbintenis van de zekerheidssteller en zijn inkomsten en vermogen.

25. De afweging waartoe de rechter wordt verplicht, laat toe de situatie van alle betrokken partijen in aanmerking te nemen. Zo kan de kwijtschelding slechts gedeeltelijk zijn, kan zij slechts de persoonlijke zekerheidssteller die kosteloos is opgetreden ten goede komen en moet er sprake zijn van onevenredigheid. Niettemin blijft het evenwicht broos, aangezien precies de aanwezigheid van de zekerheid doorslaggevend kan zijn geweest voor de bereidheid van de schuldeiser om met de schuldenaar te contracteren. Daarenboven kan bovenvermelde cascade ook in omgekeerde richting werken en de schuldeiser in gevaar brengen.

Ook vanuit maatschappelijk oogpunt moet bij de legitimiteit van de maatregel worden stilgestaan. De zorg om menswaardigheid van de zekerheidssteller bij insolventie van de schuldenaar kan haar verantwoorden. Zij tast echter de zekerheidsfunctie aan en zodoende het principe dat aangegane verbintenissen moeten worden uitgevoerd. Dit beïnvloedt de bereidheid tot contracteren en kan een prijsverhoging in de hand werken.

40. Art. I675/I6bis stipt uitdrukkelijk de toepassing van art. I287 B.W. aan.

4I. Art. $1675 / 7$, \$2, lid 2 Ger. W. 
De moeilijkheid van de evenwichtsoefening komt ook tot uiting bij de evaluatie van de mogelijkheid voor de zekerheidssteller om bevrijding te verzoeken terwijl de schuldenaar die zich objectief in een situatie van overmatige schuldenlast bevindt, nalaat het initiatief te nemen om tot de procedure te worden toegelaten. Enerzijds krijgt de zekerheidssteller nog vooraleer sprake is van samenloop bescherming tegen de aanspraken van de schuldeiser. Anderzijds vormt de insolvabiliteit van diens hoofdschuldenaar een reële bedreiging voor de zekerheidssteller, waaraan, bij stilzitten van eerstgenoemde, niet kan worden verholpen door initiatief tot de collectieve schuldenregeling dat niet van de schuldenaar uitgaat.

Ook de uitbreiding van een in het kader van een minnelijke aanzuiveringsregeling verleende kwijtschelding tot de zekerheidssteller ligt niet voor de hand. Enerzijds kan worden aangevoerd dat het vrijwillige karakter impliceert dat de schuldeiser als het ware van de vordering afstand doet, zodat de draagwijdte ervan niet dient te worden beschouwd als beperkt tot de relatie met de hoofdschuldenaar. Anderzijds kan de bereidheid de schuldenaar te bevrijden precies zijn ingegeven door de wetenschap dat de schuldeiser zich van een zekerheid heeft voorzien. Vanuit dit oogpunt lijkt de automatische uitbreiding van de kwijtschelding, die eerder in het accessoire karakter dan in van het verzekeringsaspect van de zekerheidsstelling ligt, de bereidheid tot toegevingen in het kader van de minnelijke aanzuiveringsregeling niet te versterken.

\section{Bescherming van goederen en inkomsten van de schuldenaar}

26. Vanuit het oogpunt van de waarborg op een menswaardig bestaan voor de schuldenaar en zijn gezin tijdens en na de procedure, rijst de vraag naar het lot van de goederen en inkomsten van de schuldenaar tijdens de insolventieprocedure. Dit lot is ook bepalend voor de mate waarin de rehabilitatie echt kan slagen.

Deze toetssteen illustreert opnieuw de in de collectieve schuldenregeling besloten belangenafweging. Anders dan bij een zuivere vereffeningsprocedure worden de aanzuiveringsinspanningen gespreid in de tijd om een buffer in te bouwen die de schuldenaar moet toestaan menswaardig te leven. Dit moet ook de liquidatie van zijn vermogen vermijden. Daar staat tegenover dat deze spreiding een kost en risico's voor de schuldeisers meebrengt.

27. Het belangenevenwicht heeft de Belgische wetgever er toe aangezet de algemene bescherming van het inkomen uit het beslagrech $t^{42}$ in beginsel over te nemen, met de mogelijkheid het leefgeld ${ }^{43}$ met instemming van de schuldenaar te reduceren tot minimaal het leefloon. ${ }^{44}$ Vanzelfsprekend mag deze reductie de menswaardigheid

42. Zie art. 1409 e.v. Ger. W.

43. Als gevolg van art. I675/9, §I, $4^{\circ}$ Ger. W. moeten de schuldenaren van de tot de collectieve schuldenregeling toegelaten schuldenaar voortaan betalen in handen van de schuldbemiddelaar. Als gevolg hiervan ziet de schuldenaar zijn inkomstenstroom opdrogen. Daarom heeft de schuldbemiddelaar tot taak de schuldenaar een leefgeld ter beschikking te stellen. Het betreft een maandelijkse enveloppe om de uitgaven voor een menswaardig bestaan te dekken.

44. Art. I675/9, \$4 Ger. W. Met betrekking tot het leefloon zie de wet van 26 mei 2002 betreffende het recht op de maatschappelijke integratie (B.S. 3 I juli 2002). 
niet in het gedrang brengen. Deze schijnbaar harde maatregel kan zich opdringen omwille van de ernst van de overmatige schuldenlast en het drastisch karakter van de maatregelen die zich, rekening houdend met de eveneens behartigenswaardige belangen van de schuldeisers, opdringen. In het licht van de concrete omstandigheden van het dossier dient de instemming door de schuldenaar te worden gevraagd. Hoewel dit geen automatisme is, mag de weigering geen blijk geven van onvoldoende bereidheid tot medewerking.

De begroting van het leefgeld gebeurt individueel per dossier en wordt bijvoorbeeld bepaald door de gerechtvaardigde vaste en variabele kosten van het gezin en de duur van de procedure. De schuldbemiddelaar doet hierbij een aanzet onder controle van de rechter. Hoewel rekening moet worden gehouden met de menselijke aspecten van de procedure, is deze beperking van het beschikbare inkomen en de ermee gepaard gaande terugval van de levensstandaard vaak ingrijpend.

28. Wat de bescherming van de goederen betreft, houdt de Belgische wetgever vast aan de, gedateerde, algemene lijst van niet-voor beslag vatbare (roerende) goederen. 45 Ook niet in deze lijst opgenomen goederen worden in de praktijk zelden te gelde gemaakt. Er is enerzijds de in art. $1675 / 3$ Ger. W. vervatte algemene waarborg op een menswaardig bestaan voor het gezin van de schuldenaar. Anderzijds wegen de verkoopskosten vaak niet op tegen de opbrengsten ervan, zodat de verkoop nodeloos kwetsend en stigmatiserend is. Dit neemt niet weg dat zij voor de schuldeisers een belangrijke symbolische functie kan hebben. De vraag rijst evenwel in hoeverre het hier niet eerder om vergeldingsdrang gaat, wat vermeden moet worden.

Voor de woning van de schuldenaar of zijn wagen - die van belang kan zijn bij de beroepsuitoefening - heeft de wetgever geen bijzondere bescherming voorzien. Dit lijkt verantwoord. Indien het financieel herstel een (aanzienlijke) kwijtschelding van schulden impliceert, lijkt het, rekening houdend met de positie van de schuldeisers, niet aanvaardbaar dat de schuldenaar zijn beslagbare goederen kan behouden. Ook buiten deze omstandigheid, precies om de noodzaak van een kwijtschelding af te wenden, kan de rechter de aanzuiveringsregeling laten afhangen van de verkoop van bepaalde goederen van de schuldenaar als 'passende maatregelen' die de aanzuiveringsinspanningen ondersteunen. Het spreekt voor zich dat in dergelijk hypothese nog grotere omzichtigheid geboden is, waarbij de rechter rekening moet houden met de betekenis van de goederen voor het menswaardig bestaan van het gezin en de wijze waarop het zich tot hun inkomensniveau verhoudt.

\section{Aanzuivering binnen een redelijk tijdschema}

29. De bevrijding moet binnen een redelijke tijdsspanne volgen. Een aanzuiveringsplan dat de schuldenaar verplicht een deel van zijn schulden aan te zuiveren, is vanuit maatschappelijk, economisch, juridisch en psychologisch oogpunt een redelijke eis.

45. Zie art. I408 Ger. W. 
De lengte van het plan mag echter niet tot gevolg hebben dat de schuldenaar - vooral indien hij ouder is - iedere horizon verliest waardoor het plan onredelijk wordt.

Lange aanzuiveringsplannen staan daarenboven onder grotere druk van wijzigende omstandigheden in hoofde van de schuldenaar en zijn gezin. Dit leidt op zijn beurt tot de noodzaak om procedures in te bouwen die toelaten de aanzuiveringsplannen te wijzigen en in overeenstemming te brengen met de concrete leefomstandigheden en de financiële situatie (die zowel in positieve als in negatieve zin kan wijzigen) van de schuldenaar.

Daarenboven is de schuldenaar in een aanzuiveringstraject geen volwaardig consument. Vanuit dit, misschien cynische, oogpunt komt een langdurig aanzuiveringstraject de economie evenmin ten goede.

30. De Belgische wetgeving voorziet niet in een maximale looptijd voor een minnelijke aanzuiveringsregeling. Dit werd niet nodig geacht aangezien alle betrokkenen moeten instemmen met het aanzuiveringsplan en zijn looptijd. Nochtans voert de rechter hier enige controle op uit ter gelegenheid van de akteneming van het minnelijk plan. De looptijd kan van dien aard zijn dat, rekening houdend met de leeftijd van de schuldenaar, er geen sprake meer is van een perspectief voor de betrokkene. Naast de leeftijd kan ook de gezinssituatie in aanmerking worden genomen. Bijvoorbeeld het feit dat hij opgroeiende kinderen heeft waardoor de met de aanzuivering gepaarde inspanningen extra doorwegen, kan een tegenindicatie voor een te lange looptijd zijn.

3I. Wat de gerechtelijke aanzuiveringsregeling betreft, voorzien art. I675/I2 Ger. W. (gerechtelijke aanzuivering zonder kwijtschelding) en art. I675/I3 Ger. W. (gerechtelijke aanzuivering met kwijtschelding) in een principiële duurtijd van maximum vijf jaar. ${ }^{46}$

Om in bepaalde omstandigheden de menswaardigheid te garanderen, voorziet de gerechtelijke aanzuivering zonder kwijtschelding in de mogelijkheid in hoofde van de schuldenaar om de looptijd van de gerechtelijke aanzuiveringsregeling, niettegenstaande de principiële maximale duurtijd van vijf jaar, te verlengen. ${ }^{47}$ Aangezien de aan een kwijtschelding verbonden verkoop niet kan worden afgewend bij een gerechtelijke aanzuiveringsregeling ex art. I675/13 Ger. W., lijkt de niet-verlengbaarheid van de aanzuiveringsregeling, die anderzijds anders dan de in art. I675/12 Ger. W. bedoelde aanzuiveringsregeling wel minimaal drie jaar moet duren, verantwoord. De verlengbaarheid, gecombineerd met de verkoop van de beslagbare goederen zou het toekomstperspectief van de schuldenaar wellicht te sterk hypothekeren en een marginaal voordeel voor de schuldeiser in zich dragen.

Het verzoek van de schuldenaar moet uitdrukkelijk en gemotiveerd zijn. Het moet tot doel hebben bepaalde elementen van zijn vermogen te beschermen en de eerbiediging van de menselijke waardigheid te verzekeren. Door de verlenging van de looptijd beschikt de schuldenaar over een langere tijdsspanne om zijn schulden in

46. Art. I675/12, §2, eerste lid Ger. W. en art. I675/13, §3 Ger. W.

47. Art. $1675 / 12, \$ 2$, eerste lid Ger. W. Het spreekt voor zich dat deze looptijdbeperking in beginsel niet de minnelijke aanzuiveringsregeling betreft. 
hoofdsom af te betalen. Op die manier kan een gerechtelijke aanzuiveringsregeling met gedeeltelijke kwijtschelding van schulden in hoofdsom of een totale kwijtschelding van schulden worden afgewend. Tegelijk kan de schuldenaar ook de daarmee gepaarde gaande principiële vereiste van de verkoop van zijn beslagbare activa afwenden.

Tegenover deze mogelijkheid tot looptijdverlenging staat de door de wet van I3 december 2005 gerealiseerde principiële onmogelijkheid om een gerechtelijke aanzuiveringsregeling van meer dan vijf jaar op te leggen. Zij wil een einde maken aan rechtspraak die een verlenging van de looptijd van de gerechtelijke aanzuiveringsregeling soms reeds, in weerwil van de rechtspraak van het Hof van Cassatie, ab initio bij de oplegging van de aanzuiveringsregeling voorzag. ${ }^{48}$

32. Niettegenstaande de belangen van de schuldeiser en hoewel niet de indruk mag ontstaan dat financiële rehabilitatie al te gratuit kan worden verkregen, mogen voor de schuldeisers eerder symbolische aanzuiveringsinspanningen niet té lang duren.

In deze context moet de totale kwijtschelding van schulden buiten een aanzuiveringsregeling worden begrepen Met dit aan het burgerlijk faillissement analoge concept wil de Belgische wetgever ook in de meeste hopeloze dossiers, waarbij tegenover de schuldenlast een totaal gebrek aan activa staat, een 'fresh start' mogelijk maken zonder de schuldenaars een zware procedure te doen doorlopen waarvan de (financiële) impact relatief gering is. Vanuit dit oogpunt vertegenwoordigt de aanzuiveringsregeling een nodeloze kost, niet enkel voor de samenleving en de schuldenaar, maar eveneens voor de schuldeiser die erbij betrokken blijft.

Nochtans rijst de vraag of, anders dan bij het klassieke faillissementsrecht, de aanzuiveringsregeling, hoewel op het eerste gezicht geen terugbetaling mogelijk is, niet kan worden verdedigd omdat zij aanleiding geeft tot een proces van financiële bewustwording. De begeleidende maatregelen waaruit de kern van de aanzuiveringsregeling kan bestaan - en die ook voor schuldeisers en maatschappij een belangrijk signaal kunnen zijn - kunnen de kans op structureel herstel vergroten. Dit traject laat toe te werken zowel aan een betere inkomenssituatie (als gevolg waarvan de aanzuiveringsregeling makkelijk zou kunnen worden aangepast ten behoeve van de schuldeisers), als een ander beheers- en bestedingspatroon in hoofde van de schuldenaar. Vanuit deze invalshoek lijkt een totale kwijtschelding in het raam van een aanzuiveringsregeling veeleer verdedigbaar.

De wetgever achtte deze aanpak evenwel nodeloos duur en al te belastend voor een schuldenaar wiens financiële situatie al a priori hopeloos is. Bijgevolg werd geopteerd voor een snelle liquidatie. Zonder duidelijk mandaat van de schuldbemiddelaar en de rechter lijken hefbomen voor structureel herstel inbouwbaar door de mogelijkheid er begeleidingsmaatregelen aan te verbinden (bijvoorbeeld verplichting tot volgen van budgetbeheer). De opvolging ervan is zodoende (zeer) precair.

48. Zie hierover K. Broeckx, B. De Groote en S. Voet, 'Grondige revisie van de collectieve schuldenregeling', T.P.R. 2007, p. 1565-I569, nrs. 2I-27. 
33. De bevrijding mag niet gepaard gaan met discriminatie. De schuldenaar moet opnieuw een financieel volwaardige speler worden. Er moet over worden gewaakt dat de schuldenaar niet gediscrimineerd wordt op de arbeidsmarkt, ${ }^{49}$ de toegang tot huisvesting, enz. Dit principe houdt onder meer verband met de schrapping uit kredietregistratiesystemen, zoals de Belgische kredietrisicocentrale.

34. Bij de Nationale Bank van België bestaat een Centrale voor Kredieten aan Particulieren. ${ }^{50}$ De centrale registreert de consumentenkredietovereenkomsten en de hypothecaire kredietovereenkomsten.

De centrale heeft een positief en een negatief luik. Zij registreert zowel het bestaan van kredietovereenkomsten als wanbetalingen ervan. De kredietcentrale is een instrument ter voorkoming van overmatige schuldenlast. Een kredietgever moet voorafgaand aan het afsluiten van een hypothecaire of consumentenkredietovereenkomst de kredietcentrale raadplegen. ${ }^{51}$ De raadpleging moet de kredietgever informatie verschaffen over de financiële toestand en de solvabiliteit van de kredietnemer.

Hiertoe worden ook gegevens betreffende het naar aanleiding van de collectieve schuldenregeling opgestelde bericht van collectieve schuldenregeling geregistreerd in de kredietcentrale van de Nationale Bank van België..$^{2}$ Dit is niet onbelangrijk aangezien overmatige schuldenlast niet noodzakelijk met (wanbetalingen van) consumentenkredieten of hypothecaire kredieten gepaard gaat.

35. Om zich een beeld te kunnen vormen van de financiële situatie zal de schuldbemiddelaar bij de voorbereiding van een minnelijke aanzuiveringsregeling kennis nemen van de gegevens die op naam van de schuldenaar zijn geregistreerd bij de kredietcentrale. Tevens neemt hij kennis van de op naam van de schuldenaar opge-

49. De toegang van de schuldenaar tot de procedure wordt aan diens werkgever, als schuldenaar van de toegelaten schuldenaar, ter kennis gebracht. Deze laatste is als gevolg hiervan verplicht het loon te betalen in handen van de schuldbemiddelaar.

50. Wet van Io augustus 200I betreffende de Centrale voor kredieten aan Particulieren, B.S. 25 september 200 I en Koninklijk besluit van 7 juli 2002 tot regeling van de Centrale voor Kredieten aan Particulieren, B.S. I9 juli 2002.

5I. Ter aanvulling op de informatie bij deze raadpleging verkregen, is de Nationale Bank van België bovendien gemachtigd om voor rekening van de kredietgevers ondervragingen te verrichten van het bestand van berichten van beslag, delegatie, overdracht en collectieve schuldenregeling (art. Io van de wet van ro augustus 200 I betreffende de Centrale voor kredieten aan Particulieren).

52. Art. I9 van de wet van 5 juli 1998 betreffende de collectieve schuldenregeling en de mogelijkheid van verkoop uit de hand van de in beslag genomen onroerende goederen, samen gelezen met Koninklijk besluit van 22 april 1999 tot regeling van de registratie van de berichten van collectieve schuldenregeling door de Nationale Bank van België en van hun raadpleging door de personen bedoeld in artikel I9, §2, van de wet van 5 juli 1998 betreffende de collectieve schuldenregeling en de mogelijkheid van verkoop uit de hand van de in beslag genomen onroerende goederen (B.S. I9 mei I999) en Koninklijk besluit van 20 november 2003 tot wijziging van het Koninklijk besluit van 20 november 1992 betreffende de verwerking van persoonsgegevens inzake consumentenkrediet en van het Koninklijk besluit van 22 april 1999 tot regeling van de registratie van de berichten van collectieve schuldenregeling door de Nationale Bank van België en van hun raadpleging door de personen bedoeld in artikel I9, § 2, van de wet van 5 juli 1998 betreffende de collectieve schuldenregeling en de mogelijkheid van verkoop uit de hand van de in beslag genomen onroerende goederen (B.S. I7 december 2003). 
stelde berichten van beslag, delegatie, overdracht en collectieve schuldenregeling. ${ }^{53}$ Een en ander laat hem toe de lijst van de door de schuldenaar opgegeven schuldeisers te controleren.

36. Indien de schuldenaar de collectieve schuldenregeling met succes doorlopen heeft, leidt het aanzuiveringsplan tot financiële rehabilitatie. Om te vermijden dat de historiek van overmatige schuldenlast de schuldenaar zou achtervolgen en de rehabilitatie uithollen, heeft de Belgische wetgever onder meer voorzien in de verplichting de in het raam van een collectieve schuldenregeling aangezuiverde schulden uit het negatieve luik van de kredietcentrale te schrappen. De bewaring van de gegevens betreffende wanbetalingen is beperkt tot twaalf maanden vanaf de datum van regularisatie van de kredietovereenkomst. Met de regularisatie wordt onder meer het bereiken van de einddatum van een aanzuiveringsregeling in het raam van een collectieve schuldenregeling bedoeld. ${ }^{54}$ Ook de bewaringstermijn van de door de centrale geregistreerde berichten van collectieve schuldenregeling is beperkt tot twaalf maanden vanaf het einde van de aanzuiveringsregeling. ${ }^{55}$ Aldus probeert de wetgever bijna letterlijk de idee van een schone lei te realiseren.

\section{Io Professionele omkadering}

37. Tot slot is professionele omkadering, in de vorm van juridisch advies en juridische bijstand, essentieel in het kader van insolventiewetgeving voor particulieren. Dit draagt immers bij tot de reële toegankelijkheid en het succes van de procedure.

Aan deze toetssteen is in de eerste plaats voldaan door de kosteloze juridische tweedelijnsbijstand waar de schuldenaar, door zijn toelating tot de collectieve schuldenregeling, automatisch het recht toe verkrijgt. Hij kan hiervoor een verzoek indienen bij het door de Orde van Advocaten georganiseerde Bureau voor Juridische Bijstand in het arrondissement waar de procedure is (en moet worden) ingeleid. ${ }^{6}$ Sinds I september 2006 is art. I, SI van het Koninklijk besluit van I8 december 2003 tot vaststelling van de voorwaarden van de volledige of gedeeltelijke kosteloosheid van de juridische tweedelijnsbijstand en de rechtsbijstand ${ }^{57}$ aangevuld met een $\mathrm{II}^{\circ}$. Hierdoor geniet, op voorlegging van de beschikking van toelaatbaarheid, de schuldenaar tijdens de collectieve schuldenregeling de volledige kosteloosheid. Hetzelfde geldt voor de persoon belast met overmatige schulden op voorlegging van een verklaring waaruit blijkt dat de toekenning van de rechtsbijstand of van de juridische tweedelijnsbijstand wordt aangevraagd met het oog op de inleiding van een procedure van collectieve schuldenregeling.

53. Art. I675/I0, §i Ger. W.

54. Art. I, d, samen gelezen met art. 8 van het Koninklijk besluit van 7 juli 2002.

55. Art. 5 van het Koninklijk besluit van 22 april 1999 .

56. Zie art. 508/I tot 508/20 Ger. W.

57. B.S. 24 december 2003. 
38. In de tweede plaats heeft de wetgever waarborgen ingebouwd voor de neutraliteit en professionaliteit van de schuldbemiddelaar..$^{8}$ Dit kan echter nog versterkt worden door te investeren in verplichte (na)vorming van de schuldbemiddelaars in alle, ook niet juridische, vaardigheden waarmee schuldbemiddeling en inzonderheid de collectieve schuldenregeling hem confronteert. Dergelijke vorming zou aan een voor alle schuldbemiddelaars verplichte erkenning kunnen worden verbonden. 59

Vooralsnog kunnen advocaten en ministeriële ambtenaren (waaronder gerechtsdeurwaarders en notarissen) tot schuldbemiddelaar worden aangeduid. Slechts overheids- of particuliere instellingen (O.C.M.W.'s of C.A.W.'s) moeten zijn erkend en voor de schuldbemiddeling een beroep doen op natuurlijke personen die aan de door de bevoegde overheden bepaalde voorwaarden voldoen. In de Vlaamse Gemeenschap kan een instelling voor schuldbemiddeling slechts erkenning genieten indien zij tegelijkertijd over een maatschappelijk werker beschikt die een gespecialiseerde opleiding heeft genoten of drie jaar nuttige beroepservaring kan voorleggen en een jurist met deze opleiding of ervaring tewerkstelt of er een overeenkomst mee heeft gesloten, dan wel een overeenkomst heeft gesloten met een orde van advocaten bij een balie. ${ }^{60}$

39. Een tweede vaststelling betreft de baremieke kosten en erelonen verbonden aan schuldbemiddeling in het kader van de collectieve schuldenregeling. De Belgische wetgever heeft de vergoeding van de schuldbemiddelaar vastgesteld in het Koninklijk besluit van I 8 december 1998 houdende vaststelling van de regels en barema's tot bepaling van het ereloon, de emolumenten en de kosten van de schuldbemiddelaar. $^{61}$

Deze barema's hebben tot doel de toegang tot de procedure te verzoenen met de waarborgen van een basisvergoeding die gebaseerd is op een forfaitaire raming van de aan een dossier verbonden werklast. ${ }^{62}$ Aangezien de moeilijkheid van het dossier niet noodzakelijk gecorreleerd is met de omvang van de boedel en omdat het eerder een herstel- dan een liquidatieprocedure betreft, is anders dan bij de bepaling van het ereloon van de faillissementscurator, bijvoorbeeld geen rekening gehouden met

58. Zie hierover o.m. S. Lefebvre, 'Organen van insolventie: de schuldbemiddelaar', in XXXIste P.U.C. Willy Delva, Insolventierecht 2004-2005, Mechelen, Kluwer, 2006, 39I-427.

59. Vgl. de erkenning van bemiddelaars (art. 1726 Ger. W.).

6o. Decreet van 24 juli 1996 houdende regeling tot erkenning en subsidiëring van de instellingen voor schuldbemiddeling en tot subsidiëring van een Vlaams Centrum Schuldenlast (B.S. 5 oktober I996) en het Besluit van de Vlaamse regering van 25 maart 1997 tot uitvoering van het decreet van 24 juli 1996 houdende regeling tot erkenning van de instellingen voor schuldbemiddeling in de Vlaamse Gemeenschap (B.S. 30 mei I997), zoals gewijzigd door het Besluit van de Vlaamse regering van II januari 2008 (B.S. 20 maart 2008 , eerste uitg.).

6I. B.S. 3I december 1998 . Het Koninklijk besluit geeft uitvoering aan art. I675/19 Ger. W.

62. Voor de bepaling van het ereloon van de commissaris inzake opschorting (bij het gerechtelijk akkoord) wordt daarentegen gebruik gemaakt van een schatting in concreto van het aantal werkuren nodig om de taak uit te voeren. Het uurtarief van de commissaris inzake opschorting wordt bepaald overeenkomstig de tarieven die gebruikelijk zijn bij de beroepscategorie waartoe hij behoort. Zie het Koninklijk besluit van ro augustus I 998 houdende vaststelling van de regels en barema's betreffende de erelonen en de kosten van de commissarissen inzake opschorting (B.S. I9 september i998). 
de omvang van de gerealiseerde goederen bij de bepaling van het ereloon. ${ }^{63}$ De collectieve schuldenregeling illustreert bij uitstek dat gedegen schuldbemiddeling een belangrijke inhoudelijke (kennis) en organisatorische investering van de schuldbemiddelaar vergt en een arbeidsintensieve opgave is, ongeacht de omvang van de schuldenlast.

Dit tot gevolg dat de aan de rehabilitatie verbonden inspanningen voor de schuldenaar toenemen, wat een drempel betekent. Daarenboven nemen de voor aanzuivering beschikbare middelen af en blijft een groter saldo van de schulden onbetaald of neemt de duurtijd van de aanzuiveringsregeling - en de eraan verbonden risico's toe.

40. Hoewel schuldoverlast een maatschappelijk fenomeen is, wentelt de overheid de bemiddelingskost in eerste instantie af op de individuele betrokkenen, ongeacht hun reële - daarenboven vaak moeilijk te bepalen - verantwoordelijkheid voor het ontstaan van de situatie van overmatige schuldenlast. ${ }^{64}$ Weliswaar kan de overheid zich als schuldeiser tussen deze individuele betrokkenen bevinden. De maatschappelijke bijdrage in de kosten van de aanzuivering is beperkt tot de eventuele tussenkomst van het Fonds ter bestrijding van de overmatige schuldenlast.

Hierbij passen enkele kritische bedenkingen. Het Fonds wordt gefinancierd door kredietverleners a rato van het saldo van de in de negatieve kredietcentrale geregistreerde overeenkomsten. Dit laat enerzijds toe kredietverleners te responsabiliseren. Anderzijds dragen niet uitsluitend kredieten bij tot situaties van overmatige schuldenlast. Bijgevolg lijkt de overheid enkel de usual suspects te viseren. Inspanningen dringen zich op om, niettegenstaande de praktische moeilijkheden bij de uitwerking van de modaliteiten ervan, ook andere groepen van schuldeisers op soortgelijke manier bij de financiering van het Fonds te betrekken. Bovendien rijst de vraag of niet ook de overheid, vaak zelf betrokken schuldeiser en exponent van de samenleving, baat heeft bij investeringen in curatieve maatregelen tegen overmatige schuldenlast en ten aanzien van dit maatschappelijk gegeven niet eveneens een ook financiële verantwoordelijkheid mag/moet opnemen.

Deze opmerking kadert in de vaststelling dat de financiering van het Fonds precair is. Zo maakte de wetgever een door de wet van I3 december 2005 geïntroduceerde uitbreiding van de tussenkomst van het Fonds ongedaan met art. 34 van de wet van 27 december 2006 houdende diverse bepalingen. ${ }^{65}$ De mogelijkheid voor de rechter om ook bij een toereikendheid actief - bijvoorbeeld met het oog op vergroting van de financiële ruimte voor aanzuivering of om een menswaardig bestaan te leiden - een tegemoetkoming van het Fonds te gelasten, werd hierbij beperkt. Vanuit dit oogpunt nam ook de maatschappelijke tegemoetkoming opnieuw af omdat zij in haar huidige omvang niet volstaat om de voorgenomen tegemoetkoming te dragen.

63. Zie het Koninklijk besluit van io augustus 1998 houdende vaststelling van de regels en barema's tot bepaling van de kosten en het ereloon van de curatoren (B.S. 8 september I998, err. B.S. I5 september 1998).

64. Volgens art. I675/19, \$2, eerste lid Ger. W. komt de staat van ereloon, emolumenten en kosten van de schuldbemiddelaar ten laste van de schuldenaar en wordt deze bij voorrang betaald.

65. B.S. 28 december 2006. 
4I. In het bijzonder legt de schuldbemiddelaar, naast het leefgeld, een reserve aan voor de betaling van de kosten van de schuldbemiddeling.

Indien deze uitgeput is, kan bij een aanzuiveringsregeling met kwijtschelding van kapitaalschulden een beroep worden gedaan op het Fonds, in zoverre de schuldenaar de kosten niet binnen een redelijke termijn zal kunnen terugbetalen. Dit lijkt te kunnen impliceren dat de schuldenaar in bepaalde gevallen na afloop van de collectieve schuldenregeling nog met de betaling van de aanzuiveringskosten kan worden geconfronteerd. Vanzelfsprekend komt dit de toegankelijkheid ten goede en verhoudt zich dit moeilijk met de idee van een nieuwe start.

Slechts bij een totale kwijtschelding worden de onbetaalde bemiddelingskosten ten last van het Fonds gelegd. Er moet hier worden opgemerkt dat een financiering van het Fonds, eventueel met overheidstussenkomst, die zou toelaten de bemiddelingskost integraal te dragen, de schuldbemiddelaar zou toelaten deze taak ook vanuit een structureel meer onafhankelijke positie uit te oefenen.

42. Tot slot is het belangrijk te vermelden dat een deel van de middelen van het Fonds zijn bestemd voor informatie en sensibilisering, waarmee de overheid het terechte belang van preventie in de strijd tegen overmatige schuldenlast lijkt te onderkennen. ${ }^{66}$

\section{Slotbeschouwingen}

43. De in dit preadvies gemaakte analyse van de Belgische collectieve schuldenregeling nodigt uit tot een aantal algemene besluiten die de negen invalshoeken voor de evaluatie van de procedure overstijgen.

De meest voor de hand liggende vaststelling is dat de insolventieprocedure voor particulieren in België in het laatste decennium sterk is geëvalueerd. Enerzijds kan worden gerefereerd aan belangrijke rechtspraak (vooral dan van het Grondwettelijk hof). Anderzijds moeten de wetten van 13 december 2005 worden aangestipt.

Reeds de wet van 5 juli 1998 was vrij vooruitstrevend. Niet alleen door de introductie van de idee van de rehabilitatie na afloop van een aanzuiveringsplan, maar eveneens de introductie van de gewaarborgde menswaardigheid als kader waarbinnen de terugbetaling van de schulden moet plaatsvinden. De procedure was en is dan ook een niet onbelangrijk sociaal signaal. Belangrijk hierbij is de vraag in hoeverre de procedure in haar vooruitstrevendheid niet (te) eenzijdig is geworden.

44. De procedure is, hoewel er parallellen bestaan, onderscheiden van het faillissement en het gerechtelijk akkoord. Het faillissement is een liquidatieprocedure, waar hooguit de figuur van de totale kwijtschelding zonder aanzuiveringsregeling gelijkenissen mee kan vertonen. Het gerechtelijk akkoord is een herstelprocedure. Zij heeft enerzijds tot doel faillissementen te voorkomen, doch bevat anderzijds passerelles naar het faillissement voor het geval het gerechtelijk akkoord zou mislukken. Dit

66. Zie art. 20, §3, lid I, $3^{\circ}$ van de wet van 5 juli 1998 . 
laatste is opgebouwd rond de opschorting van betaling die tegen uitvoeringsmaatregelen beschermt. Zij moet de schuldenaar, die tijdelijk zijn schulden niet kan voldoen of wier onderneming bedreigd wordt door moeilijkheden die op korte termijn kunnen leiden tot het ophouden van betalen, toelaten om samen met een commissaris inzake opschorting, een herstel- en/of betalingsplan uit te dokteren om het economisch herstel en de financiële sanering van de onderneming te realiseren.

De collectieve schuldenregeling heeft, onder meer door de aanzuiveringsregeling gepaard te laten gaan met begeleidende maatregelen, tot doel om door remediëring van de psychosociale aspecten van overmatige schuldenlast bij te dragen tot het structureel financieel herstel van de schuldenaar.

De collectieve schuldenregeling is ondergebracht in het Gerechtelijk Wetboek, meer in het bijzonder in Deel V over het bewarend beslag, de middelen tot tenuitvoerlegging en de collectieve schuldenregeling. Vaak zijn middelen tot tenuitvoerlegging, die de procedure opschort, knipperlichten voor overmatige schuldenlast en wijzen zij op de noodzaak van een samenloop waarbinnen een globale curatieve aanpak mogelijk is. In het verlengde van de bescherming van de schuldenaar bij beslag is bovendien in de collectieve schuldenregeling, meer doorgedreven dan in het faillissement, gestreefd naar een balans tussen de uitvoering en de bescherming van de schuldenaar (en zijn gezin). Dit is noodzakelijk aangezien de garanties voor de schuldenaar moeten worden afgewogen tegenover de legitimiteit van de aanzuiveringsmaatregelen bij insolventie.

45. De sterktes en zwaktes van de procedure van de collectieve schuldenregeling zijn nauw met elkaar verbonden.

De complexiteit van de procedure, waarvan de grenzen nog vaak onder druk van de realiteit worden afgetast, houdt in de eerste plaats verband met de wil in iedere stand van de procedure een gezond evenwicht tussen de conflicterende belangen te verzoenen. Het doel van de procedure bestaat er immers in de schuldenlast op een menswaardige wijze aan te zuiveren. Hierbij aansluitend houdt zij verband met de wil om sociale overwegingen in de procedure te integreren. Dit kan leiden tot moeilijke verhoudingen met klassieke concepten uit het verbintenissen- en uitvoeringsrecht die eveneens belangrijke peilers van de procedure zijn.

In het licht van deze diverse belangen speelt de schuldbemiddelaar, als draaischijf en motor van de procedure, een cruciale rol. Zowel bij het zich informeren over de overmatige schuldenlast, het initiatief nemen tot een aanzuiveringsregeling als bij het opvolgen ervan, is zijn interventie essentieel. Door deze rol met verve op te nemen kan hij bijvoorbeeld minnelijke aanzuiveringsregelingen stimuleren die omwille van de wilsautonomie waarop zij zijn gebaseerd, garant staan voor een sterker engagement en bijgevolg grotere slaagkansen.

De schuldbemiddelaar rapporteert aan de rechter. Deze laatste bewaakt de naleving van de procedure en kan, bijvoorbeeld bij de redactie of de aanpassing van de aanzuiveringsregeling, boven de partijen beslissingen treffen indien de schuldbemiddelaar er niet in slaagt hen met elkaar aansluiting te laten vinden. Tevens kan hij een niet loyaal meewerkende schuldenaar sanctioneren en hem, door middel van de herroeping, het voordeel van de procedure ontnemen. 
46. De schuldenaar van zijn kant verliest, anders dan bij het faillissement, het beheer van zijn goederen niet. Hij komt bijgevolg niet onder het bewind van de schuldbemiddelaar. Dit is belangrijk om de eigenwaarde van de schuldenaar te waarborgen. In de door de toelaatbaarverklaring ontstane samenloop zijn de handelingen die de schuldenaar mag stellen wel beperkt. Het mag enkel gaan om handelingen die kaderen binnen een normaal vermogensbeheer. Handelingen die de schuldeisers of de gelijkheid onder hen raken, mogen slechts met rechterlijke machtiging worden gesteld. Zoniet zijn zij niet tegenwerpbaar aan de schuldeisers en kunnen zij tot herroeping aanleiding geven. In het kader van dit vermogensbeheer moet de schuldenaar, in wiens handen diens schuldenaars niet meer bevrijdend kunnen betalen, over leefgeld beschikken.

De bepaling van de ruimte waarbinnen het beheer van de schuldenaar kan plaatsvinden is bijzonder relevant om het vertrouwen te behouden van de schuldeisers. Zij worden immers geconfronteerd met een procedure die hen misschien wel toelaat - soms na dure, maar vruchteloze eerdere invorderingspogingen - een (onverhoopt) deel van hun vordering te recupereren, maar hen het initiatief daartoe ontneemt. De aanzuiveringsprocedure, die hen bijvoorbeeld met een (gedeeltelijke) kwijtschelding kan confronteren, moeten zij ondergaan.

Als schuldeisers minder snel verzet aantekenen tegen een ontwerp van minnelijke aanzuiveringsregeling of minder snel om herroeping verzoeken, mag dit immers geen gevolg zijn van apathie, waaronder diep ongenoegen met de procedure schuilgaat, maar moet dit een uiting van vertrouwen zijn in de wijze waarop de procedure en de actoren ervan ook met hun belangen rekening houden. Slechts dan kan een toename van het aantal minnelijke aanzuiveringsregelingen betekenen dat de hier toegelichte maatregelen ter ondersteuning ervan positief bijdragen tot het bereiken van echte unanimiteit.

47. Vermoedelijk houdt het precaire karakter van het evenwicht ook verband met het particuliere karakter van de insolventie. Aangezien de insolventieprocedure zich, anders dan bijvoorbeeld het faillissement of het gerechtelijk akkoord, niet onmiddellijk in de economische context afspeelt, liggen zowel voor de rechtstreeks betrokkenen als de samenleving, het niet louter individuele karakter van het belang van de aanzuivering als de oorzaak van de schuldenlast minder voor de hand.

De rol van de rechter en bij uitstek de bemiddelaar zijn vanuit het oogpunt van het optimaal functioneren van de collectieve schuldenregeling op langere termijn van essentieel belang. In het bijzonder omwille van de tijdens de analyse van de procedure meermaals geuite vraag of de wetgever de sociale overwegingen niet te sterk laat prevaleren op de aanzuiveringsgedachte.

Hierbij dient de bevoegdheidsoverdracht in 2005 ten voordele van de arbeidsgerechten, waarmee de wetgever de sociale dimensie van de problematiek wil beklemtonen, te worden vermeld. Omwille van het belang van voormeld belangenevenwicht, mag worden aangenomen dat hierin niet de echte beweegreden van de wetgever heeft geschuild en dat de arbeidsgerechten zich bewust zullen zijn van het belang de wet niet met minder aandacht voor alle betrokkenen toe te passen. 
48. De complexiteit van de procedure en de problematiek waaraan zij moet verhelpen vergen van de schuldbemiddelaar bijzondere, niet uitsluitend juridische, vaardigheden. Hij weet zich immers valk geconfronteerd met enerzijds de verzuchtingen van de schuldeisers en anderzijds de persoonlijke moeilijkheden van de schuldenaar en diens gezin. Zij kunnen de situatie van overmatige schuldenlast mee in de hand hebben gewerkt en de aanpak ervan is bijgevolg vaak essentieel voor het structureel karakter van een nieuwe financiële start. Diplomatieke talenten en een pragmatische, probleemoplossende, benadering zijn dan ook essentieel.

Het verdient dan ook aanbeveling om te investeren in juridische en psychosociale vorming van de schuldbemiddelaar en de mogelijkheid om als schuldbemiddelaar op te treden hiervan afhankelijk te maken.

Tevens moet erover worden gewaakt dat de vergoeding van de schuldbemiddelaar, ongeacht de financiële relevantie van de samenloop, voldoende correspondeert met de sleutelfunctie die hij heeft in de procedure en het maatschappelijke belang ervan. Hierbij rijst de vraag of de overheid, indien zij overmatige schuldenlast als een reëel maatschappelijk probleem erkent, voldoende investeert in de ook curatieve benadering ervan. Een eventuele uitbreiding van de financieringsbasis van het Fonds ter bestrijding van overmatige schuldenlast tot andere groepen schuldeisers en/of beter nog een eigen engagement, dienen op zijn minst te worden overwogen.

49. In het licht van het al meermaals aangehaalde noodzakelijke evenwicht is niet enkel de juridische structuur van de collectieve schuldenregeling essentieel, maar ook de houding van de actoren ervan. De aandacht gaat hierbij vooral uit naar de schuldenaar.

De schuldenaar die om toelating verzoekt, vraagt een gunstmaatregel aan. Dit kan ten koste van de belangen van zijn schuldeisers gaan. Dat zijn loyauteit tijdens de procedure onontbeerlijk is, spreekt voor zich. Deze situeert zich onder meer op het vlak van de transparantie van zijn vermogen.

Hierbij rijst de vraag of de aan de schuldenaar, onder meer bij het toelatingsverzoek, opgelegde verplichtingen en de onderzoeksmogelijkheden ter beschikking van de schuldbemiddelaar volstaan. Zo moet worden opgemerkt dat de mogelijkheid tot opheffing van het beroepsgeheim van de derde bij wie om inlichtingen over de vermogenstoestand van de schuldenaar wordt verzocht, door het Grondwettelijk Hof is vernietigd voor wat de advocaat betreft. De vraag rijst of het maatschappelijk belang van het evenwicht dat in de collectieve schuldenregeling vervat zit en het initiatief van de schuldenaar om tot de procedure te worden toegelaten, een versoepeling van het beroepsgeheim niet kunnen rechtvaardigen.

50. Vanuit het oogpunt van het structureel karakter van het herstel en de maatschappelijke aanvaardbaarheid van de rehabilitatie, rijst de vraag of het, naar analogie van het faillissementsrecht, afstappen van de idee van de noodzaak van een aanzuiveringsregeling bij de introductie van de totale kwijtschelding wenselijk is geweest.

Een structurele oplossing impliceert wellicht dat zij niet enkel orde brengt in de financiële situatie van de schuldenaar, maar van zijn gezin. Aangezien het vermogen een sterk persoonlijk karakter vertoont heeft de wetgever ervoor gekozen de collectieve schuldenregeling als een individuele procedure te ontwerpen. De impact van de 
situatie van overmatige schuldenlast betreft, in strikte zin door de werking van het huwelijksvermogensrecht, vaak beide partners, zodat men zich kan afvragen of het individueel karakter van de procedure geen nuance behoeft.

5I. In Europese context zijn de verschillen tussen de wetgevingen van de diverse lidstaten in het licht van voormelde beginselen van dien aard dat de tijd wellicht nog niet rijp is voor een verregaande harmonisering van het regelgevend kader voor insolventieprocedures voor consumenten. Grensoverschrijdende gevallen van overmatige schuldenlast, waarvan het belang door toenemende mobiliteit enkel zal vergroten, worden vooralsnog best binnen het raamwerk van de Europese Insolventieverordening aangepakt. Hierbij moet er over worden gewaakt dat alle insolventieprocedures voor consumenten in dit internationaal privaatrechtelijk instrument worden geïntegreerd. Evenzeer moet aandacht worden besteed aan het eventueel functioneel bijsturen van de Insolventieverordening in functie van de bijzonderheden van de curatieve aanpak van overmatige schuldenlast bij particulieren.

De curatieve aanpak van overmatige schuldenlast bij particulieren is, zoals hierboven aangetoond, een gevoelige materie. $\mathrm{Zij}$ houdt verband met de manier waarop samenlevingen bijvoorbeeld tegenover de rol van het krediet aankijken en hoe zij de belangen tussen de bij overmatige schuldenlast betrokkenen afwegen. Dit maakt harmonisatie niet vanzelfsprekend. Desondanks rijst de vraag of België, met zijn eerder genuanceerde en sterk ontwikkelde procedurewetgeving, niet kan bijdragen tot initiatieven tot harmonisering. De in dit preadvies gebruikte toetsingscriteria kunnen hierbij een uitgangspunt vormen. 